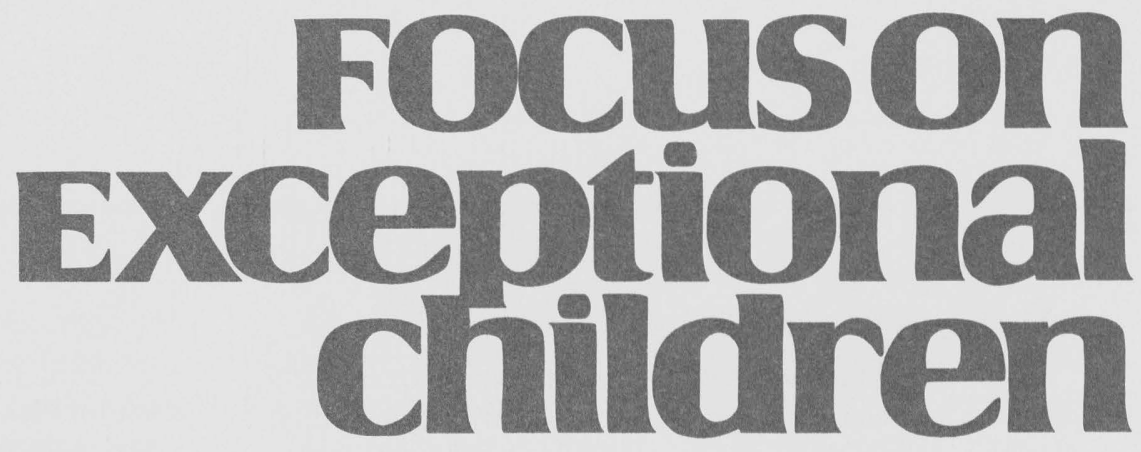

\title{
Crisis Intervention with Adolescents with Learning Disabilities
}

\section{Lewis Putnam, Ph.D.}

Here are just a few of the challenges we face:

- Every 31 seconds an adolescent becomes pregnant

- Every 2 minutes an adolescent gives birth

- Every 78 seconds an adolescent attempts suicide

- Every 90 minutes an adolescent commits suicide

- One million adolescents drop out of high school (Children and Teens Today Newsletter, 1987; Mann, 1986).

This article provides a discussion of several social issues that all adolescents must deal with daily. This information is critical to special education teachers because students with learning disabilities (LD) are not immune to involvement in these and other social issues.

Depression and suicide, alcohol and other drug use, teenage sexuality and school dropout, along with many other pressing social issues, place adolescents at risk for social, emotional, and psychological problems. Adolescents often are involved with more than one of these social issues. They attend schools where they are expected to be attentive, complete assignments, learn in a classroom setting, earn credits toward high school graduation, and eventually enter the world of work or attend an institution of higher education. Many adolescents succeed despite their involvement in these social issues, but increasing numbers need social, emotional, and educational interventions aimed at increasing their coping skills or at reducing their involvement. Adolescents with LD are at even greater risk for involvement with these social issues than their nonhandicapped peers. Thus, special education teachers should understand the incidence, possible causes, identification, and appropriate interventions.

\section{PROBLEMS OF ADOLESCENCE}

Adolescence is a developmental stage characterized by experimentation, confusion, risktaking behaviors, and a sense of immortality and invulnerability. Teachers often hear student comments such as, "I got so blasted Saturday night that I don't remember anything," or "It's not cool to use a condom!"

M. Lewis Putnam, Ph.D., is a researcher at Washington Research Institute in Seattle, Washington. 


\section{Public School Responsibility}

Public schools increasingly are expected to address social issues that previously were the responsibility of the family, religious organizations, and social agencies. Educators often feel overwhelmed and underprepared to deal with adolescents at-risk for depression and suicide, alcohol and other drug use, sexual activities, school dropout, and other complex social issues facing today's adolescents.

\section{Adolescents At-Risk}

Many professionals use the term at-risk to describe a certain category of students. Never precise, the meaning of this term varies considerably in research and in classroom practice. McWhirter et al. (1993) defined "at risk" as "a set of presumed cause/effect dynamics that place the [adolescent] in danger of negative future events" (p. 6) such as not graduating from high school (Slavin, Karweit, \& Madden, 1989). Those authors contended that "at-risk" also might be viewed as a relative term, like a series of steps along a continuum rather than as a distinct category. The continuum in Figure 1 ranges from adolescents who are minimally at-risk to those who are involved more actively in risk-taking behaviors.

\section{Focuson
Exceptional children}

ISSN 0015-511X

FOCUS ON EXCEPTIONAL CHILDREN (USPS 203-360) is published monthly except June, July, and August as a service to teachers, special educators, curriculum specialists, administrators, and those concerned with the special education of exceptional children. This publication is annotated and indexed by the ERIC Clearinghouse on Handicapped and Gifted Children for publication in the monthly Current Index to Journals in Education (CIJE) and the quarterly index, Exceptional Children Education Resources (ECER). The full text of Focus on Exceptional Children is also available in the electronic versions of the Education Index. It is also available in microfilm from Xerox University Microfilms, Ann Arbor, MI. Subscription rates: Individual, $\$ 30$ per year; institutions, \$40 per year. Copyright (c) 1995, Love Publishing Company. All rights reserved. Reproduction in whole or part without written permission is prohibited. Printed in the United States of America. Second class postage is paid at Denver, Colorado. POSTMASTER: Send address changes to:

Love Publishing Company

Executive and Editorial Office

1777 South Bellaire Street

Denver, Colorado 80222

Telephone (303) 757-2579

Edward L. Meyen

University of Kansas

Richard J. Whelan

University of Kansas Medical Center
Glenn A. Vergason Georgia State University
Stanley F. Love

Publisher
Kristin Kennedy Editorial Assistant
FIGURE 1

The At-Risk Continuum

Minimal Risk

favorable demographics

positive family, school, and social interaction

limited psychosocial and environmental stressors

\section{Remote Risk}

negative demographics

less positive family, school, and social interaction some stressors

\section{High Risk}

negative family, school, and social interaction

numerous stressors

development of personal at-risk markers

negative attitudes and emotions

skill deficiencies

\section{Imminent Risk}

development of gateway or threshold behaviors and activities

\section{At-Risk Category}

at risk for more intensive maladaptive behavior

adolescent's activity solidly places him or her in the at-risk category

at risk for other categories

Source: McWhirter, J. J., McWhirter, B. T., McWhirter, A. M., \& McWhirter, E. H. (1993). At-risk youth: A comprehensive response. Pacific Grove, CA: Brooks/Cole. Reprinted with permission.

Minimal risk. Adolescents who come from high socioeconomic settings, attend good schools, and have loving, caring relationships with their friends and families are assumed to be at minimal risk for involvement with these social issues. These adolescents, however, cannot be considered as "no risk," because no adolescent can escape altogether the influences of events such as death, divorce, and so on. The extent to which these and other events lead the adolescent to risktaking behaviors depends upon factors such as age, developmental level, personality, available resources (social and mental health support), coping skills, and so on.

Remote risk. An adolescent reaches the point on the continuum at which risk-taking behaviors, though still remote, seem more possible because of negative demographic markers involving family, school, and so forth. A combination of these markers moves the adolescent along the at-risk continuum. For example, an adolescent who is from an "impoverished, dysfunctional, ethnic minority family and who attends a poor school in a marginal neighborhood" (McWhirter et al., 1993, p. 8) is further along the continuum than an adolescent with fewer markers. Most adolescents in this group do survive these difficulties and function well. Therefore, although these markers are important, they are only partially predictive of at-risk status for an adolescent.

High risk. The next set of circumstances that moves a adolescent along the continuum is the demographic markers combined with an adolescent's negative attitudes or emo- 
tions. Adolescents at this point often experience depression, anxiety, and exhibit aggressive and risk-taking behaviors. These markers often signal that an adolescent is not coping with various stressors (e.g., poor grades, few friends) and certain demographic markers.

Imminent risk. As the adolescent moves along the continuum, at-risk status becomes even greater. At this point the adolescent may begin to use alcohol or other drugs occasionally to reduce some of the stressors or may appear to be depressed at times. These behaviors, referred to as threshold behaviors, often progress to increasingly more frequent and severe risk-taking behaviors. For example, cigarette use is considered a threshold to alcohol use, which can be a threshold to marijuana use, which in turn can be a threshold to crack cocaine use.

At-risk. The final step in the continuum is reached when the adolescent participates in behaviors that define the at-risk categories. According to McWhirter et al. (1993), these adolescents no longer are at-risk because they may have already attempted suicide, become involved in the abuse of alcohol and other drugs, become sexually active, or dropped out of school.

\section{TEENAGE DEPRESSION AND SUICIDE}

Suicide is a growing problem among adolescents. The number of 15- to 24-year-olds who have committed suicide has risen 200\% (Tomlinson-Keasey \& Keasey, 1988) and now ranks as one of the top three causes of death for individuals under 24 years of age (Guetzloe, 1989).

\section{How Many Adolescents Attempt Suicide}

Suicide ideation (thoughts about suicide) and parasuicide (attempted suicide) both show a significant increase with age, particularly during adolescence (Rutter, 1986). As many as 7,000 adolescents commit suicide each year, and 400,000 to 1 million attempt to do so (Capuzzi \& Golden, 1988; Robertson \& Mathews, 1989). According to the results of a Gallup poll, $33 \%$ of 1,152 adolescents 15 to 19 years old have thought about suicide, $15 \%$ have seriously considered killing themselves, and $6 \%$ actually have made attempts (Peterson, 1991). In the United States, $20 \%$ of male suicides and $14 \%$ of female suicides involve adolescents (Hendlin, 1982; Robertson \& Matthews, 1989). Females attempt suicide three times as often as males, but males complete suicide three times as often as females. This difference results from the more violent means, such as guns, that males use. The rate of completion by teenage girls, however, is increasing rapidly (Steele, 1983). These estimates are low because suicides often are reported inaccurately. Because of family embarrassment or religious beliefs or because of school and community discomfort, many suicides are reported as accidental or undetermined deaths (McWhirter et al., 1993).
Knowledge of the incidence of suicide by adolescents with LD is even less clear, as only a few studies directly compare depression and suicide by adolescents with mild disabilities and those without disabilities. The limited number of studies, however, suggests a discouraging picture. Adolescents with mild disabilities seem to have higher anxiety levels, more frequent and more serious bouts of depression, and higher rates of suicide than adolescents without disabilities (Dollinger, Horn, \& Boarini, 1988; Hayes \& Sloat, 1988; Maag \& Behrens, 1989; Ritter, 1989).

\section{Societal Myths Related to Suicide}

Our society presents a negative view of suicide and of individuals who attempt suicide. As a result, many myths are associated with suicide. Accurate knowledge is one of the keys to understanding the causes and characteristics of adolescents who are at risk for taking their own lives. The most common myths are shown in Table 1.

\section{When an Adolescent May Be Suicidal}

For many, adolescence is filled with stressful events and adjustments. We must be able to distinguish between the typical turmoil that occurs during adolescence from turmoil that is life-threatening. Too many adolescents at risk for suicide have been viewed mistakenly and sometimes tragically as simply going through a stage (Metha \& Dunham, 1988).

The exact cause of suicide remains a mystery. Professionals generally agree that suicidal behavior results from a complex interaction of numerous factors with no single cause (Hawton, 1986; Pfeffer, 1986). Thus, no one type of adolescent is more suicidal than another. It could be any student from the homecoming queen to the most reserved and quiet student in class.

The single most predictive factor for adolescent suicide is a previous attempt (Shaffer, 1974). Any problem that contributes to feelings of depression, worthlessness, helplessness, or hopelessness has the potential to trigger suicidal behavior in a vulnerable adolescent. Table 2 summarizes the most common warning signs that an adolescent may be thinking about committing suicide.

Certain psychological, social, and school characteristics can help distinguish between adolescents who are able to cope with their turmoil and those who are at risk for taking their own lives.

Psychological characteristics. These characteristics include suicidal threats or statements, extreme changes in behavior, and "getting the house in order" (e.g., giving away prized possessions) (Guetzloe, 1987). Frederick (1985) contended that suicidal individuals often suffer from the "three H's: haplessness, helplessness, and hopelessness" (p. 15). For example, suicidal adolescents may have had a series of mis- 
TABLE 1

Societal Myths Related to Suicide

\begin{tabular}{|l|l|}
\hline Myth & Fact \\
\hline People who talk about suicide do not attempt suicide. & $\begin{array}{l}8 \text { out of } 10 \text { people who attempt to kill themselves do leave } \\
\text { clues to their intent. Simply talking about suicide, however, } \\
\text { does not mean a person will not attempt. Every verbal threat } \\
\text { or reference to dying must be taken seriously. To discount a } \\
\text { person's threat or reference is a direct rejection of his or her } \\
\text { cry for help. }\end{array}$ \\
\hline
\end{tabular}

Suicide happens without warning.

Suicide often seems to be a sudden, unprovoked act only because we missed the warning signs. Sometimes, however, the clues are much more indirect unless we know what to look for. Statements such as "You won't have to worry about me much longer," or behavior such as withdrawing from friends or giving away many of their possessions can be signs that a person is preparing to die. The point is that expressed statements about dying must be taken seriously. We must learn the warning signs that the suicidal person provides.

Suicidal persons are fully intent on dying.

Most suicidal persons are ambivalent about dying. Many, especially teens and younger children, never believe they will die but that they will be rescued. Ninety percent of teenage suicide attempts are made in the home between early afternoon and midnight when parents are likely to find them. The fact that clues and warning signs most often precede the attempt also points to the ambivalence. It must be remembered, however, that the ambivalence does not reduce the risk involved.

People who attempt suicide are mentally ill.

The overwhelming despair a suicidal person feels can be caused by a sudden emotional upset, a long physical illness, the sudden loss of a loved one, or the feeling that he or she truly is a burden to others. A frequent theme of suicidal children is that they feel they are the cause of their parent's unhappiness. Suicide in most cases is not the act of psychotic persons, but persons who feel that the pain in their lives will not die, so they must. Only $12 \%$ of those who commit suicide are mentally ill. The attitude that suicide is the act of a deranged mind is exactly what keeps many potentially suicidal persons from being more open about their feelings. They fear that if they reveal their suicidal feelings, others will attempt to commit them to a psychiatric hospital. This reaction is, by far, the least helpful and is most often unnecessary.

Children are not capable of knowing how to kill themselves.

Television has given adolescents the knowledge necessary to kill themselves. They are aware of what acts are potentially lethal.

Children who attempt suicide have parents who are callous, insensitive, ignorant, and incapable of loving a child.

Most parents are sometimes the last to see the pain in their child because they love the child so much that they don't want to recognize that their child is in pain. Most parents, however, once approached, will do whatever is necessary to help their child.

People who attempt suicide are merely looking for attention.

People who threaten to attempt suicide are reaching out for help, not "merely" attention. 
fortunes over which they had little or no control, such as their parents' divorce and a subsequent move (haplessness). The adolescent may not have the coping skills, such as seeking help or advice from a friend or professional, to deal with these events (helplessness). As a result, the adolescent may feel hopeless, and suicide may seem to be the only answer ("I don't know what else to do!").

Another key psychological characteristic, depression, is highly correlated with suicidal behavior. Estimates of the prevalence of depression among the general school-aged population have ranged from $1.8 \%$ to $13.9 \%$ (Pfeffer, Zuckerman, Plutchik, \& Miznuchi, 1984), with higher rates reported among older adolescents. We must become aware of the signs of depression among adolescents so we can provide appropriate interventions or refer the adolescent to the school counselor or to a local social or mental health agency.
According to the Diagnostic and Statistical Manual of the American Psychiatric Association, Third Edition, Revised (DSMIII-R) (APA, 1987), a consideration of major depression requires at least five of the following nine behaviors and must include either a depressed mood or loss of interest or pleasure. These behaviors must have been evident nearly every day for at least 2 weeks and represent a change from the adolescent's previous behaviors:

1. Depressed or irritable mood

2. Loss of enjoyment or interest in normally pleasurable activities

3. Change in weight, appetite, or eating habits

4. Problems with sleeping

5. Psychomotor agitation or slowness

6. Loss of energy; feeling of fatigue

7. Feelings of worthlessness, inadequacy, self-reproach, selfdepreciation, loss of self-esteem

TABLE 2

\begin{tabular}{l} 
- Sudden changes in behavior \\
- Drinking, taking drugs \\
- Decline in school performance \\
- Inability to concentrate \\
- Withdrawing from others \\
- Studying all the time to the exclusion of outside activities and friends \\
- Fighting physically with family members \\
- Running away \\
- Giving away possessions \\
Verbal Clues \\
$\begin{array}{l}\text { Direct: } \\
\text { "I feel like killing myself." } \\
\text { "Sometimes she makes me so mad, I feel like hanging (shooting, etc.) myself." } \\
\text { Indirect: } \\
\text { "Everyone would be better off without me." } \\
\text { "If this happens again ..." } \\
\text { "I just can't take anymore...." } \\
\text { about it, ongoing discussion about it, etc. }\end{array}$ \\
Situational Clues \\
$\begin{array}{l}\text { - Loss of relationships, friends, etc. } \\
\text { - Loss of status or sudden traumatic event (not making grades or team, or exclusion from peers) } \\
\text { - Divorce of parents } \\
\text { - Violence within the family } \\
\text { - Parental overemphasis on achievement } \\
\text { - First year of college } \\
\text { - Period of time immediately following a long bout of depression } \\
\text { - Physical problems along with changes in behavior or performance }\end{array}$ \\
\hline
\end{tabular}

Source: Steele, W. (1983). Preventing teenage suicide. Novato, CA: Ann Arbor Publishers. Reprinted with permission. 
8. Diminished ability to attend, think, or concentrate

9. Recurrent thoughts of death or suicide.

Social Characteristics. One of the major social characteristics of teenage suicide is the cluster suicides that follow or imitate another suicide. Teenagers who are part of a cluster may attempt suicide out of an impulsive reaction to someone else's suicide. When one adolescent commits suicide, the act somehow becomes "normalized" for others, and those who previously had experienced the "three H's' may begin to see suicide as a viable option. The incidence of cluster suicides suggests that one adolescent's suicide is a powerful event that influences others to take their own lives (Sturner, 1986).

A second social characteristic is related to the adolescent's home situation. Suicidal youths are more likely than non-suicidal youths to have lost a parent. Specifically, $50 \%$ to $72 \%$ of adolescent suicide attempters or completers have lost a parent through death, divorce, or abandonment (Tomlinson-Keasey \& Keasey, 1988; Tomlinson-Keasey, Warren, \& Elliott, 1986).

Violence in the home is another social characteristic. Some researchers have reported that nearly $60 \%$ of suicidal adolescents have experienced some degree of sexual or physical abuse at home (Kosky, 1983). In addition, a family history of suicide is prevalent in adolescents who attempt or complete suicide. According to one study, nearly $38 \%$ of adolescent suicide attempters had a close relative who had committed suicide (Metha \& Dunham, 1988).

School Achievement Characteristics. Suicide also is related to the adolescent's school achievement. In one study of 12-to 15-year-olds hospitalized for self-destructive behavior and threats of suicide, $20 \%$ were not enrolled in school, $45 \%$ reported that they did not attend school regularly, and $50 \%$ were performing below their expected grade level (Gispert, Wheeler, Marsh, Davis, 1985). As we are all too aware, poor school achievement often initiates a spiral of self-doubt, failure, and negative thoughts, which may lead to depression or suicide attempts.

\section{Identification}

In addition to being aware of these psychological, social, and school achievement characteristics, two useful methods are available to determine an adolescent's suicide ideation. Teachers who feel uncomfortable about using these procedures should refer the adolescent to another professional, such as the school counselor.

Interviews. Interviews, which can disclose the severity and lethality of suicide ideation, probably are the most effective and informative way to determine the adolescent's suicide risk (McWhirter, 1993). These are conducted with adolescents who appear to be depressed or suicidal and with their parents, teachers, and friends. Information to be solicited during the interview includes: (a) History of the presenting problem (depression, anxiety, etc.)

(b) The family structure and relationships (divorce, physical or sexual abuse, alcoholism, etc.)

(c) The developmental, medical, and academic history of the adolescent

(d) The status of interpersonal relationships

(e) Previous suicide attempts

(f) Verbal warning signs

(g) Behavioral warning signs

(h) Any stressor events that may trigger a suicide attempt (McWhirter et al., 1993, p. 195).

If suicide ideation is suspected, the degree of risk of the adolescent acting upon those thoughts must be determined. Because suicide ideation by itself is not a great risk, the severity of the threat or suspicion depends on the specificity and the lethality of the method of choice.

Therefore, we need to be knowledgeable about the risk factors of a suicidal threat as listed by Steele (1983):

1. Suicidal plan. The more specific a person is about the way he or she will die, the greater is the likelihood of an attempt.

2. Availability of Method. The risk is higher whenever the method is readily available. (Example: a person who says he or she has thought of carbon monoxide poisoning but does not have a car is less at risk than the person who has a car available.)

3. Location. If a person has determined the place and it is accessible, the risk of suicide is high, especially if the location is inaccessible to others.

4. Time. If the time is specified, the risk is higher. Teens most often attempt suicide in their own homes between mid-afternoon and midnight.

5. Ingestion of alcohol or drugs. Whenever anyone is drinking or taking other drugs and talking suicide, the risk is very high because drugs reduce self-control and significantly increase impulsivity.

6. Accessibility for rescue. If a person plans to commit suicide at a time or place when or where no one is expected or able to get to, the risk is high.

7. Lack of support. If the person has no friends, parents who are not concerned, or if the suicidal person refuses to give information necessary to reach friends or those who could help, the risk is high. A recent loss coupled with talk of suicide portends high risk. A loss that may seem insignificant to us can be painful for that person, especially if followed by other losses. Loss may be in the form of a friend or a pet, for example. Not getting an "A," not winning an election, not being accepted into peer groups, or being rejected from a peer group can be significant losses.

8. Previous attempts.. Those who have attempted suicide in the past are always at high-risk for suicide.

9. Illness. Chronic physical illness or long-standing emotional problems raise the risk for suicide.

Self-report Inventories. The second method that can be used to determine the level of depression in adolescents is the self-report inventory. Two useful inventories are the Beck Depression Inventory (BDI) (Beck et al., 1961) and the Scale of Suicide Ideation (SSI) (Beck, Kovacs \& Weissman, 1979). 
The BDI indicates whether an adolescent is severely depressed and at-risk for suicide. The SSI focuses more on attitudes about living and dying, the characteristics and specificity of suicidal ideation, and background factors such as previous suicide attempts.

By using interviews and self-report inventories and by being aware of the warning signs and myths associated with depression and suicide, we are better able to identify adolescents who may be depressed or experience suicide ideation. Before accurate identification is possible however, we must be aware of two primary difficulties:

1. Adolescents tend not to actively volunteer information about their emotions, turmoil, and so forth (Garrison, Lewinsohn, Marsteller, Langhinrichsen \& Lann, 1991).

2. Adolescents are reluctant to say that they are thinking of taking their own life or that they may be thinking of death (Reynolds, 1985).

\section{Prevention, Intervention, and Postvention}

Suicide prevention tends to focus on the factors that lead to suicidal ideation or parasuicide, while intervention is directed to treatment after an unsuccessful suicide attempt. Postvention consists of activities for surviving family members, friends, the school, and the community after a parasuicide or successful suicide.

Prevention. Most school-based suicide prevention programs deal primarily with detecting signs of depression and suicide ideation. In addition, prevention efforts attempt to help students to be successful in school, to grow emotionally, and to achieve up to their academic potential. School-based prevention efforts include modifying the student's school situation (e.g., changes in schedule), providing a tutor, or reducing the student's credit load. In addition, students with LD may need a change in their individualized education programs (IEPS), such as reduced time in either the special or general education classroom, and specific instruction in social skills or problem solving.

Intervention. Intervention efforts usually are initiated after an adolescent is determined to be depressed or has exhibited suicidal behaviors or attempted suicide. The focus here should not be on why adolescents view suicide as an option to their current situation but, rather on solving problems, in the home, school, or community, so suicide is no longer considered an option. The major stressors (e.g., grades, friends) that triggered the suicidal behavior or thoughts should be identified, and steps taken to reduce the pressures through school-based counseling or support groups. Again, a change in IEP may be necessary for students with LD, to address specific stressors.

At times an adolescent may have to be referred to services outside of the school system, such as a counseling center or a mental health agency. Regardless of whether interventions are in or outside of the school, the immediate task is to provide re- lief from feelings of the "three H's", to explore alternatives to suicidal behavior, and to instill feelings of being in control of their life (Frederick, 1985). With appropriate interventions, depressed and suicidal adolescents usually show considerable improvement (Peck, 1985), but warning signs can recur. More than $40 \%$ of adolescents who commit suicide are thought to have made previous attempts (Shaffer, 1974), and 3\%-10\% do so within 15 years (Otto, 1972). Therefore, school-based prevention and intervention efforts must be combined with long-term intervention and follow-up efforts, because a adolescent with suicidal tendencies may be at risk for several years after the initial threat or attempt (Guetzloe, 1988).

When teachers find themselves in a situation of interacting with a depressed or suicidal adolescent, the following set of guidelines proposed by McGee and Guetzloe (1988) may be helpful.

1. Never take suicide threats or gestures casually.

2. Don't be afraid to bring up the subject of suicide.

3. Question the student closely and carefully about a possible suicide plan.

4. Do not debate the morality of suicide.

5. Identify the major stresses or events that precipitated the suicidal behavior.

6. Do not convey the message that suicidal thoughts are ridiculous or that make the student suffer guilt.

7. Encourage the student to use other support systems such as parents, friends, church leaders, school personnel, or a counseling center.

8. If the suicidal behavior was precipitated by the loss of a romantic relationship, don't downplay it. The adolescent may view such a loss as the end of any hope for a loving relationship.

9. Don't leave the suicidal student alone.

10. Dispose of anything in the immediate environment that could be used as a weapon.

11. Mention school or community events that will be coming up later in the day, the next day, or the next week that might elicit their interest.

12. Be aware of the student's responses to your statements.

13. Be sure that the student has the telephone number of a crisis center, the suicide hotline, or a member of the school staff.

14. Do not promise to keep a student's suicidal behavior a secret.

15. Try to get a commitment from the student that he or she will not hurt himself or herself and that if he or she feels any kind of suicidal impulse, he or she will call a teacher, a counselor, or a hotline worker.

16. Always make a referral to a school guidance counselor or other appropriate professional.

These guidelines are not to be used in lieu of notifying parents or guardians or seeking other professional help.

Postvention. Despite prevention and intervention efforts, all adolescent suicides cannot be prevented. When a suicide does occur, the school should provide postvention activities. These efforts deal with issues such as cluster suicides and the grief and shock of family members, friends, and other students.

Adolescents will talk about the suicide whether we do or do not provide them with the opportunity. They need a 
chance to remember that having suicidal thoughts is not unusual and thinking about suicide does not mean they are destined to attempt suicide. If they talk about the suicide without adult leadership, however, their conclusions may be incorrect or negative. The leadership that the school can provide can help adolescents who might have suicidal ideations. Berkan (1986, pp. 29-30) suggested the following postvention activities.

The building principal should brief all teachers and staff on the situation.

- The building principal should request assistance from the district's psychologists, social workers, and counselors to spend several days in the school and/or district talking to small groups of students about their feelings and reactions to the suicide.

- All first-hour or homeroom classes should be informed about the facts of the situation and given an opportunity to have a short discussion of their feelings and be told about the small group sessions.

The immediate peer group of the student who has committed suicide should be identified and called in at once for special sessions with the support staff.

- All students need to be told as to whom to ask for help if they or a friend are thinking of suicide.

- Support groups should be scheduled for those who need them during school time.

Do not dismiss school; students need to follow a normal schedule as much as possible.

- Do not encourage a general student body attendance at the funeral if it is held during school hours; excuse only those students who have a parental request to attend.

Do not dedicate a room, garden, etc., to the student's memory.

If the students or staff want to do something, in memory of the student, suggest helping to plan a suicide prevention effort in the school or community.

Emphasize that suicide is not a good choice to solve problems, that help is available, and that people care.

Emphasize that no one is to blame, not friends, parents, or teachers; the student chose to die by suicide and no one forced it on the student.

\section{ALCOHOL AND OTHER DRUG USE}

Alcohol and other drug use among adolescents is widespread and has remained stable at high levels since 1975. Marijuana remains the most commonly used drug, followed by stimulants, inhalants, hallucinogens, sedatives, and tranquilizers (Johnston, O’Malley, \& Bachman, 1986). The average age at which alcohol consumption begins is 12 years, 5 months, and 23\% of young people between ages of 12 and 18 have a serious drinking problem (Horton, 1985). Regardless of the substance used and the age at consumption, even occasional use can have disastrous results. The leading cause of death in adolescents is accidental death, related to the consumption of alcohol in at least $40 \%$ of cases (American Academy of Pediatrics, 1988).

\section{Incidence}

Although the substance of choice among adolescents is alcohol, estimates of alcohol consumption and other drug use vary greatly depending upon definitions. Results of two nationwide studies indicated that anywhere from $60 \%$ to $66 \%$ of high school seniors nationwide reported alcohol consumption during the month prior to the study, $4.2 \%$ - $5 \%$ of seniors reported that they drank every day, and $37.5 \%$ reported at least one incident of heavy drinking (five or more drinks in a row). In addition, about $2 \%-6 \%$ admitted to using stimulants, 9\% used inhalants, and 5\% had used cocaine. Furthermore, $16 \%-33 \%$ reported having experimented with marijuana (Newcomb \& Bentler, 1989).

Limited data are available on the prevalence of alcohol and other drug use by adolescents with mild disabilities. Existing data are mixed, stemming primarily from clinical studies and geographically limited samples, as well as from studies with questionable technical adequacy. Devlin and Elliott (1992) found that $51 \%$ of a sample of students classified as behavior disordered (BD) showed patterns of high drug use. Only $14 \%$ of a matched nondisabled control group showed similar rates of usage. Only $28 \%$ of the BD students reported no drug use, compared with $74 \%$ of the control students. Others (see Dean, Fox, \& Jensen, 1985; DiNitto \& Krishef, 1984; Issacs, Buckley, \& Martin, 1979; Krishef, 1986) have contended that the incidence of alcohol and other drug use in adolescents with disabilities may be greater that it is among the general population. Still others (Elmquist, Morgan, \& Bolds, 1989; Leone, Greensburg, Trickett, \& Spero, 1989) see no reason to believe that adolescents with disabilities have higher levels of substance use than nondisabled students.

These and other reported incidence rates probably underestimate the prevalence and incidence of drug use by adolescents. Most research studies do not include school dropouts, who are at even higher risk for alcohol and drug abuse.

\section{Why Do Adolescents Use Alcohol and Other Drugs?}

The reasons for alcohol and other drug use among adolescents are difficult to determine. Typical reasons for use of alcohol and other drugs often are linked to social influences (e.g., peer use of drugs), whereas reasons for abuse often are tied to internal processes (e.g., use of alcohol and other drugs as medication against depression, anger, frustration) (Long \& Scherl, 1984).

Research suggests that some environmental, behavioral, psychological, and social risk factors are so consistently associated with alcohol and other drug use that they can be considered true causal factors (Newcomb \& Bentler, 1989). This information can be used to determine the likelihood of alcohol and other drug use by students and then used to provide appropriate interventions. The more risk factors with which 
an adolescent is associated, the greater is the probability of alcohol and other drug use.

The most reliable predictor of future alcohol and other drug use is prior use (McWhirter et al., 1993). Adolescents who use alcohol and other drugs before age 15 have more problems of abuse in later life (Kellam \& Simon, 1980). Risk factors for alcohol and drug abuse that have been identified by numerous researchers include (American Academy of Pediatrics, 1988; Capuzzi \& LeCoq, 1983; Horan \& Strauss, 1987; MacDonald \& Blume, 1986; Webb, Baer, McLaughlin, McKelvey, \& Caid, 1989):

\author{
Early and persistent behavior problems \\ Low commitment to school \\ Peer rejection in the elementary grades \\ School failure \\ Antisocial and deviant behavior \\ Tolerance for deviance \\ Sensation-seeking \\ Peer and parental approval and use of alcohol and other drugs \\ Poor relationship with parents \\ Family history of alcoholism or other drug use or abuse \\ Peer use of alcohol and other drugs \\ Depression \\ Low self-esteem \\ Poor parent-child communications.
}

\section{Use Versus Abuse}

Many adolescents experiment with alcohol and other drugs but perform well in school and go on to lead productive lives. Their use does not necessarily equate to abuse. With this in mind, we must keep the entire issue of alcohol and other drug use versus abuse in perspective. Because there is such a fine line between use and abuse, some informal identification procedures may be helpful. We must consider the context, frequency, type, and purpose for which alcohol or other drugs are used.

Informally, one of the best ways to determine an adolescent's use of alcohol and other drugs is through our own knowledge of the issue and the relationship we have established with students. The more we know about the students, the better the chances are that we may pick up on signs of alcohol and other drug use, as listed in Table 3.

In addition to these warning signs, teachers should be knowledgeable about the most common drugs adolescents use, their street names, and their effects. Also, to be able to distinguish between the occasional user from the adolescent whose use has moved to abuse, teachers should be familiar with the patterns of progressive alcohol and drug use, shown in Table 4.

A more formal means of determining an adolescent's alcohol and other drug use is the adolescent drinking index (ADI) (Harrell \& Wirtz, 1989). The ADI is a 24-item scale that measures the severity of drinking problems of adolescents.
TABLE 3

Signs of Alcohol and Drug Abuse

\section{Changes in Performance:}

- Distinct downward turn in grades-not just from Cs to Fs, but from As to Bs and Cs

- Assignments not completed

- Loss of interest in school; extracurricular activities

- Poor classroom behavior such as inattentiveness, sleeping in class, hostility

- Missing school for unknown reasons

- In trouble with school, work, or the police

- Memory loss

Changes in Behavior:

- Decrease in energy and endurance

- Changes in friends (secrecy about new friends with different lifestyles)

- Secrecy about activities (lies or avoids talking about activities)

- Borrows lots of money, or has too much cash

- Mood swings, excessive anger, irritability

- Preferred style of music changes (pop rock to heavy metal)

- Starts pulling away from the family, old friends, and school

- Chronic lying, stealing, or dishonesty

- Hostile or argumentative attitude; extremely negative, unmotivated, defensive

- Refusal or hostility when asked to talk about possible alcohol or other drug use

- Slurred speech

Changes in Appearance/Physical Changes:

- Weight loss or gain

- Uncoordinated

- Poor physical appearance or unusually neat; striking change in personal habits

- New interest in the drug culture (drug-related posters, clothes, magazines)

- Smells of alcohol, tobacco, marijuana

- Frequent use of eyedrops and breath mints

- Bloodshot eyes

- Persistent cough or cold symptoms (e.g., runny nose)

- Always thirsty, increased or decreased appetite, rapid speech

- AOD paraphernalia (empty alcohol containers, cigarettes, pipes, rolling papers, baggies, paper packets, roach clips, razor blades, straws, glass or plastic vials, pill bottles, tablets and capsules, colored stoppers, syringes, spoons, matches or lighters, needles, medicine droppers, toy balloons, tin foil, cleaning rags, spray cans, glue containers, household products)

Source: Elmquist, D. L. (1991). School-based alcohol and other drug prevention programs. Intervention in school and clinic, 27, 10-19. Reprinted with permission.

Severity is measured by determining the number of different areas (e.g., school, grades) in which the adolescent has had alcohol-related difficulties and the extent or intensity of the problem in those areas. 
TABLE 4

Patterns of Progressive Drug Abuse

\section{EXPERIMENTATION}

Behavior

Little effect

Denial of negative consequences
Frequency of Use

1 to 5 times

(total)
Emotional State

Excitement/daring

Mild euphoria

Possible discomfort

Mild guilt

\section{SOCIAL/SITUATIONAL}

Behavior

Decreased academic performance

Loss of interest in hobbies

Loss of interest in special activities

Begins to seek out drug-using friends

Changes in clothing habits

Some uncharacteristic behavior

\section{Frequency of Use}

2 to 4 times

per week

\section{Emotional State}

Excitement

Being "in" with the crowd

Feels better with drug than without it

Less guilt-"Drugs are OK,

I can handle them."

\author{
HABITUAL \\ Behavior \\ Most friends use drugs \\ Beginning of family problems \\ due to drug use \\ Major loss of interest in \\ school and other activities \\ Impulsiveness \\ Erratic mood swings \\ Uses drug alone
}

Frequency of Use

Daily use

\title{
OBSESSIVE/DEPENDENT \\ Behavior
}

Skips school regularly

Weight loss or gain

Messy, unclean appearance

Loss of ability to concentrate

Severe paranoid or depressed thoughts

Dangerous aggression, suicidal thoughts

Stealing to obtain drugs

\section{Emotional State}

"Need" for euphoric state

Highs are very high, and

lows are very uncomfortable

More guilt and depression

Source: Kerr, M. M., Nelson, C. M., \& Lambert, D. L. (1987). Helping adolescents with learning and behavior problems. Columbus, OH: Merrill. Reprinted with permission.

\section{Prevention and Intervention}

Prevention programs are the most common form of intervention for alcohol and other drug use, for students who have not yet experimented with the substances. At the same time, treatment for threshold drug use is instituted for students who are already users.

Many school-based prevention programs are provided through extracurricular clubs and activities that are open to all students and require no special training or selection process. These programs alone cannot be expected to have a significant effect on alcohol and other drug use and related problems. They should be part of a comprehensive school-based alcohol and other drug use program. The following are a few examples of clubs and activities that schools may offer to their students.

Students Against Driving Drunk (SADD). SADD meets regularly as a school club to promote the nonuse of alcohol and other drugs by peers and their parents, particularly when driving. A major component of this program is a contract for life, in which the adolescents and parents agree in writing to call for help or transportation if they are in a situation where they have been drinking and need to go home. SADD sponsors activities such as putting up posters in stores, restaurants, and bars; giving presentations in the community; arranging for speakers at school-wide assemblies; and giving presentations to students in middle and elementary schools to encourage early commitment to preventing alcohol and other drug use.

Just Say No Clubs. These clubs advocate the nonuse of alcohol and other drugs among its members and classmates. Members receive current and accurate information regarding alcohol and other drug use, as well as training in how to say no to peers, how to have fun without using alcohol and other 
drugs, and how to support each others' nonuse. Meeting during and after school, they often sponsor alcohol- and drugfree activities for the club and the entire school.

Lock-ins. The lock-in is an overnight alcohol- and drugfree activity sponsored by parents, students, or other clubs. Participating students engage in activities such as volleyball, basketball, swimming, and watching videos on a weekend evening. Students obtain parental permission and are not allowed to arrive or leave between certain hours, usually 9:00 P.M. until 7:00 A.M. the following morning. Lock-ins often have a special theme, and the school or local groups or agencies donate money, food, and prizes. The students are locked in to help prevent alcohol and other drug use. Sufficient supervision and administrative support are essential for success of these events.

Adventure-based programs. These programs are designed to fill the adolescent's need for adventure and risk-seeking behaviors. They provide stimulating and exciting activities as alternatives to alcohol and other drug use. Students build selfconfidence and self-esteem and learn group problem solving and teamwork as they develop new skills and find new strengths. Canoeing, camping, mountain climbing, sailing, and hiking are some of the many possible activities.

Mini-courses and wellness days. Schools offer these programs to promote individual well-being and fun without alcohol and other drug use. For one day or all week students participate in presentations by community volunteers and professionals with themes such as wellness, hobbies, noncompetitive games, alcohol and other drug-use issues, and skills in resisting peer pressure and saying no.

School climate teams. Schools sponsor positive school activities that build school spirit and community pride. The goal is to prevent alcohol and other drug use by making the school a better place to be -more caring, nurturing, and personal. Activities include a special day for encouraging friendship, decorating lockers for birthdays, and special events that give students a sense of belonging and bonding within the school.

To ensure that these clubs and activities are effective (Contrucci, 1991):

Activities should be comfortable and safe for all participants.

A variety of individual, small-group, and whole-group activities should be offered to add diversity and interest to the program.

- Activities should be flexible to meet individual school, and community needs.

- Participation must be voluntary.

- Realistic expectations should be set for each activity.

Advisors and school staff must receive basic training. (p. 47)

Many educational materials are available to teachers. These can be incorporated in daily instruction or utilized as part of the activities of these clubs and activities.

\section{TEENAGE SEXUAL ACTIVITY}

During the developmental stage of adolescence, sexuality takes on new dimensions. Feelings become more intense, relationships become more complex, and the consequences of sexual activities are altered radically. These changes affect not only the behavior of adolescents but also the behavior of their families, peers, and educators. Despite public opposition from a variety of sources, the need for adequate school-based sex education programs is pressing (Romaneck \& Kuehl, 1992). Issues related to adolescents' sexual activities are broad and complex, including sex education, the use of contraceptives, date/acquaintance rape, sexually transmitted diseases (STDs), sexual orientation and sexual harassment.

\section{Extent of Adolescent Activity}

Although the age of first sexual intercourse varies by gender and ethnicity, the majority of adolescents are sexually active by age 18 (Hofferth, Kahn, \& Baldwin, 1987; Orr, Wilbrant, Brack, Rauch, \& Ingersoll, 1989). In a Time/CNN telephone survey of 500 teenagers, Gibbs (1993) found that $19 \%$ of 13 - to 15 -year-olds and $55 \%$ of $16-17$-year-olds have had sexual intercourse. Further, $61 \%$ of teenage girls reported that they have had multiple sexual partners, up from $38 \%$ in 1971. In addition, $61 \%$ of the same population reported using birth control every time they had sex; $26 \%$ reported sometimes, and $13 \%$ reported never using birth control.

\section{Why Do Adolescents Become Sexually Active?}

The reasons adolescents become sexually active are varied. Economic status, educational goals and attainment, perceived life options, parental involvement, and familial role models are among the most influential factors associated with adolescent sexual activity. Additional factors include the adolescent's values of independence and achievement, level of selfesteem, and peer influence (Muccigrosso, Scavarda, Simpson-Brown, \& Thalacker, 1991).

Family factors are highly associated with adolescents' decisions about being sexually active. Adolescents with working mothers and from single-parent families may be more likely to be sexually active (Fick, 1984). Beyond the effects of income and educational status females whose older sisters are role models and those from large families seem to be more sexually active. The extent of sexual activity by adolescents also is related directly to the quality of parent-child communication in the home. The more involved that parents are in the lives of their adolescent, the less likely their children are to be active sexually (Foster, 1986; Paget, 1988).

Sexual activities commence at a younger age in male and female adolescents who live in poverty, teenage males and females who are low achievers educationally, and females whose mothers and older sisters are low educational achiev- 
ers (Foster, 1986). According to Gibbs (1993), "In the inner cities the scarcity of jobs and hope for the future invites kids to seek pleasure with little thought of the fallout" (p. 63).

\section{Sex Education Programs}

The consequences of an adolescent's sexual behavior are so potentially serious for themselves, their families, and society that learning and practicing responsible sexual behavior is imperative. The overall goal of sex education is to teach adolescents sexual responsibility and to promote the "positive perception of an individual's sexuality" (Kempton, 1988, p. 24). Adolescents learn sexual responsibility as they grow up in a family, by watching and copying the way responsible adults behave. Adolescents need to know that good relationships can suffer from acting upon one's sexual feelings. Unless adolescents understand the meaning of sexual responsibility, they are unprepared to engage in any sexual activity.

Sexual responsibility can be summarized as:

-both partners discussing birth control and agreeing to use it every time to prevent an accidental pregnancy

- both partners being honest about their sexual health and agreeing to use condoms to prevent sexually transmitted diseases (STDs)

- knowing that sex involves commitment and mutual consent

- understanding the positive and negative consequences that sex can have in their lives (Stang, 1989, p. 3).

Although sex education is still highly controversial, one study indicated that $85 \%$ of parents favor sex education in the schools and believe it fosters a healthy attitude toward sex (Harris, 1987). Much of the debate over teaching sex education in the public schools focuses on the morality of and our own attitudes toward human sexuality. As a result, it is a difficult issue on which to build consensus among teachers, administrators, and parents. The issue is complicated further by the flaunting of sexuality in the media, the lack of appropriate role models who practice responsible sexual behavior, and societal attitudes regarding sexuality.

In describing the needs for sex education for adolescents with disabilities, Shapiro (1981) stated:

Exceptional children experience the same physical and emotional changes that [nondisabled] children do, as well as the same anxiety which often accompanies adolescence. Thus, they must cope with all the emotional conflicts of their [nondisabled] teenage counterparts in addition to those produced by their handicaps. (pp. 25-26)

\section{Price (1987) concurred that}

[adolescents with handicaps] are influenced by the same pressures affecting the sexual decision making of every adolescent and teen, such as peer pressure, movies, and television. The differences lie in the [dis- abled] person's lack of appropriate information about physical and emotional changes of adolescence, sexuality, and birth control (p. 154)

Conger (1988) recommended three general approaches to sex education: (a) family-life planning, (b) increasing the accessibility of contraceptives to adolescents, (c) and enhancing the life options of adolescents.

Family-Life Planning. All students need current, relevant, accurate, and appropriate family-life education from the early school through high school years. Unfortunately, many students receive little information about sexuality from their parents. Only $30 \%$ of 13 - to 15 -year-olds and $27 \%$ of 16 - to 17 year-olds reported that they learned the most about sex from their parents; $26 \%$ of the 13 - to 15 -year-olds and $37 \%$ of the 16 to 17 -year-olds reported learning about sex from their friends, Gibbs (1993). This is discouraging because we all have heard the type of information about sex that students hear from their friends (for example, "If you have sexual intercourse while standing up, the girl can not become pregnant").

Although sex education in the context of family-life planning is important, it is not sufficient to resolve the problem of adolescent sexual activity. Sex education improves knowledge, but little conclusive proof exists that behavior is influenced by knowledge alone. Therefore, educational programs that work on improving relationships, boosting self-esteem, and teaching decision-making skills must be combined with life-planning programs (McWhirter et al., 1993).

Increased accessibility to contraceptives. A second approach to sex education is the availability of contraceptive options to sexually active adolescents. Decisions about birth control are complicated. Age at onset of sexual activity, family income, belief in the risks associated with unprotected sexual activity, and the availability of confidential contraceptive services are crucial variables in adolescents' use of contraceptives (Muccigrosso et al., 1991).

Contraceptives cannot be forced on adolescents, but they should be available. Access can be provided best through community- and school-based clinics that offer comprehensive, easily accessible, and high-quality health services. School-based clinics are particularly useful so sexuality can be dealt with in the context of overall health care by a school nurse who is aware of adolescents' special sexuality concerns and needs. The various methods of contraceptives available to adolescents are varied, controversial, and confusing. Therefore, adolescents should ask themselves some serious questions about their choice of contraceptives, such as:

Would an accidental pregnancy be a big problem for me and my partner?

- How safe is this method for me?

How easy is this method to use? Will I use it the right way every time, even if it sometimes is a hassle? 
$\square$ How much will this method cost to use? Can I afford it?

How does my partner feel about birth control? Can we work together to use this method?

Will I feel embarrassed about using this method? Will my partner feel embarrassed? Will I use it even if I feel embarrassed?

How do I feel about touching my body?

How often do I have sex? Do I want a method that is always in my body? Or can I pick a method to use only when I have sex?

Do I have more than one sexual partner?

Do I have religious or moral feelings about using birth control? Does this method fit with my religious beliefs?

At this point, the few clinics that provide comprehensive health services, including dispensing contraceptives, have shown promising results. In one school district the overall annual rate of first-time pregnancies was reduced from 80 per 1,000 to 29 per 1,000 ; repeat pregnancies were reduced to $1.4 \%$, compared to $33 \%$ nationally (Kirby, 1984; Schorr, 1988).

Using contraceptives every time an adolescent has sexual intercourse can help protect against pregnancy and STDs, however, the most commonly-used from of contraceptive, the use of condoms, is still not $100 \%$ foolproof. Condoms can break, partners can be careless, and mistakes can happen. The only surefire method of contraception is abstinence. Adolescents should take the attitude that being abstinent does not mean they are not grown up but, rather, they are being sexually responsible.

Until the majority of adolescents elect abstinence, those who are sexually active should be urged to practice safe sex. Safe sex means more than using contraceptives. It also requires knowing your partner and your partners sexual history. A person is having sex not only with the partner but also with whomever the partner has ever had sex with (Adams \& Gullotta, 1989).

Enhanced life options. A third approach to sex education attempts to improve adolescents' life options. McWhirter et al. (1993) contended that "when young people feel good about themselves and have a clear vision of a successful and selfsufficient future, they will be motivated to avoid pregnancy" (p. 147). In addition, Edeleman (1987) proposed that "the best contraceptive is a real future" (p. 58). A future requires opportunities to build academic and work-related skills, job opportunities, assistance with life-planning, and access to comprehensive-health services. Adolescents who are working toward personal and economic self-sufficiency tend to be more sexually responsible (McWhirter et al., 1993).

Sexually Transmitted Diseases. To many adolescents, STDs (formerly called venereal diseases) are not a concern. Thus, the risks for adolescents' contracting an STD are extremely high. Any sex education program offered in the public schools must include information on STDs, including the human immunodeficiency virus (HIV) that causes the ac- quired immune deficiency syndrome (AIDS). Short of abstinence, there is no surefire way to prevent contracting STDS.

The rates of STDs are escalating in adolescents. More than 2.5 million adolescents contract an STD annually (Office of Population Affairs, 1988). Nearly one-fourth of adolescents contract some STD each year (Gibbs, 1993). Adolescents must understand how STDs are contracted and their symptoms, as shown in Table 5.

\section{TABLE 5}

The Most Common Sexually Transmitted Diseases

\begin{tabular}{|c|c|c|c|}
\hline STD & Cause & Symptoms* & Transmission \\
\hline HIV & virus & $\begin{array}{l}\text { general illness } \\
\text { swollen glands } \\
\text { pneumonia } \\
\text { skin cancer } \\
\text { (Kaposi's sarcoma) }\end{array}$ & $\begin{array}{l}\text { sexual contact } \\
\text { (via blood, semen) } \\
\text { blood transfusion } \\
\text { dirty needles } \\
\text { mother to fetus }\end{array}$ \\
\hline Chlamydia & bacteria & $\begin{array}{l}\text { itching or burning } \\
\text { in genital or } \\
\text { urinary areas }\end{array}$ & $\begin{array}{l}\text { sexual contact } \\
\text { mother to fetus }\end{array}$ \\
\hline $\begin{array}{l}\text { Giardia } \\
\text { diarrhea }\end{array}$ & bacteria & $\begin{array}{l}\text { diarrhea } \\
\text { abdominal pain }\end{array}$ & $\begin{array}{l}\text { sexual contact } \\
\text { blood } \\
\text { feces }\end{array}$ \\
\hline Gonorrhea & bacteria & $\begin{array}{l}\text { discharge from } \\
\text { penis or vagina }\end{array}$ & sexual contact \\
\hline $\begin{array}{l}\text { Herpes } \\
\text { Type I } \\
\text { Type II }\end{array}$ & virus & $\begin{array}{l}\text { painful sores } \\
\text { around mouth } \\
\text { and/or vagina } \\
\text { burning or pain } \\
\text { during urination }\end{array}$ & sexual contact \\
\hline Syphilis & bacteria & $\begin{array}{l}\text { pimple-like sores } \\
\text { on genitals }\end{array}$ & $\begin{array}{l}\text { direct sexual } \\
\text { contact with sore } \\
\text { mother to fetus }\end{array}$ \\
\hline $\begin{array}{l}\text { Vaginal } \\
\text { infections }\end{array}$ & $\begin{array}{l}\text { bacteria } \\
\text { fungi } \\
\text { yeasts }\end{array}$ & $\begin{array}{l}\text { bad-smelling } \\
\text { vaginal discharge } \\
\text { pain during } \\
\text { intercourse }\end{array}$ & $\begin{array}{l}\text { sexual contact } \\
\text { some infections } \\
\text { spread on objects } \\
\text { (towels, douche } \\
\text { equipment) }\end{array}$ \\
\hline
\end{tabular}

Genital warts virus

warty growths in genital area

sexual contact mother to infant

*may not experience all of these or may be asymptomatic

Source: Scott, M. (1988). Family living and sex education (p. 126). New York: Globe. Reprinted with permission.

The incidence of STDs in adolescents has increased because:

1. More adolescents are sexually active.

2. Adolescents tend to have more sexual partners.

3. Many adolescents who are asymptomatic do not know that they have an STD and spread the disease unknowingly (Gale, 1989). 
AIDS is an STD caused by the human immunodeficiency virus (HIV). Over time, HIV damages the body's immune system, resulting in life-threatening infections and cancers. These illnesses are called opportunistic diseases and do not develop in healthy people.

Without doubt, AIDS is the most dangerous of the STDs that adolescents risk through their sexual activity. Because at this time AIDS is always fatal, adolescents who engage in high-risk behavior-principally, unprotected sexual intercourse or intravenous (IV) drug use are vulnerable to contracting HIV. The number of adolescents infected with HIV is unknown, but it is believed to be much higher than the prevalence of AIDS in adolescents and is doubling each year (Brooks-Gunn, Boyer, \& Hein, 1988).

Approximately $1 \%$ of those diagnosed with AIDS are adolescents (Centers for Disease Control, 1989); however, individuals 20 to 29 years of age constitute $21 \%$ of those with AIDS (Hein, 1989). Given the 7- to 10-year latency period between HIV infection and the diagnosis of AIDS (National Academy of Sciences, 1989), 20\% of the individuals diagnosed in the 20-29 year-old range were infected during adolescence (Centers for Disease Control, 1989). The source of infection varies substantially by gender: $38 \%$ of males are infected by homosexual activity and $37 \%$ by hemophilia; females are more likely $(45 \%)$ to be infected through heterosexual activity (Centers for Disease Control, 1989).

Until researchers find a cure for AIDS or a vaccine for HIV, the only weapon against the epidemic is education. Many adolescents receive contradictory and confusing information, not only from peers but also from parents and teachers. Adolescents' lives and the lives of all their sexual partners depend on their having accurate information about AIDS. This is not an overstatement or a scare tactic. Adolescents no longer can afford to think about the pleasures of sex without knowing the risks of contracting the HIV virus.

A number of studies have found significant deficiencies in adolescents' AIDS-related knowledge and beliefs (Hingson, Strunin, Berlin, \& Heeren, 1988; Strunin \& Hingson, 1987). Many beliefs related to AIDS put adolescents at risk for exposure to the HIV virus. For example, $12 \%$ of a national sample believed that birth control pills provide some protection against HIV infection, and 23\% believed that one can tell whether a person has AIDS by looking at them (Anderson et al., 1990). In addition, Tatum (1988) contended that adolescents often associate HIV/AIDS with gays and bisexuals ("the gay disease"), which frequently leads to homophobia (fear and mistrust of gays and lesbians).

Much of this misinformation is the result of hastily conceived programs, curricula, and educational materials that provide inaccurate information on HIV and AIDS. To ensure that the information shared with students is accurate, it must be obtained from reliable sources. The local public health depart- ment, Red Cross chapter, local and national AIDS agencies, and the public library can provide or recommend up-to-date, accurate information and educational materials.

Information provided to adolescents about HIV/AIDS should take into account the following information:

1. The risk of becoming infected with HIV can be virtually eliminated by not engaging in sexual activities and by not using illegal IV drugs.

2. Sexual transmission of HIV is not a threat to uninfected individuals who engage in monogamous sexual relations.

3. HIV can be transmitted through sexual contact with an infected person, by using needles that an infected person has used, and from an infected mother to her infant before or during birth.

4. Although no transmission from deep, open-mouth ("French") kissing has been documented, it theoretically could transmit HIV from an infected to an uninfected person through direct exposure of mucous membranes to infected blood or saliva.

5. Adolescents who engage in sexual intercourse with individuals who are at risk or whose infection status is unknown should use a latex condom and a water-based lubricant to reduce the likelihood of becoming infected.

6. Behavior that prevents exposure to the HIV virus also may prevent unintended pregnancies and exposure to STDs (Morbidity and Mortality Weekly Report, 1988).

Regardless of the amount of information provided to adolescents about HIV/AIDS, many continue to engage in sexual activities. These adolescents can take several precautions to greatly reduce their risk for contracting HIV (American College Health Association, 1990; Gale, 1989):

1. Make careful choices about sexual activity in (a) choosing whether to be sexually intimate, (b) choosing a partner, (c) choosing how to be sexually intimate, and (d) choosing when to be sexually intimate.

2. Communicate assertively with your sexual partner and negotiate for safer sexual practices.

3. Develop skills to express your feelings and concerns.

4. Remove alcohol and other drug use from the context of sexual activities.

5. Use latex condoms and water-based lubricants for sexual intercourse.

6. Do not share IV needles.

\section{Date/Acquaintance Rape}

Dating violence is "a pattern of abusive and coercive behaviors or actions whereby one dating partner seeks to control the other," and sexual abuse is "any sexual activity forced upon a person without his or her consent" (Tomaszewski, 1991, p. 5). All adolescents, males and females, should recognize that forcing anyone into unwanted sexual activity is rape. Forced sex is illegal, even if the person is a friend, a relative, or a date.

Rape is the most frequently committed violent crime in the United States today, and violence in dating couples does exist in adolescent relationships. Coles and Stokes (1985) re- 
ported that $14 \%$ of adolescent females in their study said they had been raped. When asked to identify the rapist, they indicated the following:

\begin{tabular}{lc}
\hline Identity of Rapist & Percentage \\
\hline friend & 30 \\
stranger & 29 \\
boyfriend & 16 \\
relative & 13 \\
neighbor & 9 \\
gang rape & 4 \\
\hline
\end{tabular}

These abusive behaviors rarely stop without some form of intervention. Violence in an early intimate relationship is as an indicator of violence in future adolescent and adult relationships (Tomaszewski, 1991). Clearly, education about date/acquaintance rape is a necessary step toward prevention and early intervention.

The goals of educational programs are "to provide adolescents with information about the dynamics of violence, teach interpersonal relationship skills that could reduce the likelihood that one partner will be abusive or abused, and provide resources to either change the abusive behavior or help an abused teenager leave the relationship" (Tomaszewski, 1991, p.4). Education should focus on sexual responsibility and "sex as a loving act" (Gale, 1989, p. 120). Sex requires two consenting persons and requires that each person set his or her own limits and be accepting of their partner's limits. All adolescents should be advised to give a clear and firm message in setting their limits and not to let themselves get talked or bullied into a situation they do not want (Gale, 1989). When a partner says "no," it means NO.

Teachers cannot prevent their students from being in situations where they are forced to participate in sexual activity without their consent. Nevertheless, teachers can offer some suggestions for lessening this risk:

1. If you feel uncomfortable about going somewhere or being alone with someone, don't go.

2. Be cautious of someone who invades your personal space by doing things such as standing or sitting too close, staring at your breasts or crotch, or touching you more than you want; tell him or her clearly to stop it.

3. Be careful of someone who is domineering and selfish, who tries to get what he or she wants at your expense.

4. Be especially alert at parties involving alcohol and drugs; they lower resistance and self-control.

5. Don't accept a ride home or go somewhere alone with someone you just met.

6. Always have a back-up to get a ride home or a way out of a potential risky situation.

7. For girls - be aware that boys may misinterpret a girl's manner of dress or behavior, and be prepared to set your limits.

8. If you get in a situation in which you are being coerced, pressured, threatened, or forced, respond quickly and firmly, flee or try to flee, fight back and yell (Gale, 1989, pp. 122-124).

\section{Sexual Orientation}

Among the many controversial topics in school-based sex education programs, none has raised so many red flags as that of sexual orientation, "the emotional and physical attraction a person feels for the [opposite] and/or same sex" (Humm, 1992 , p. 14). Orientation to the opposite sex is heterosexuality; to the same sex, homosexuality; and to both sexes, bisexuality. Many female homosexuals prefer to be called lesbians, whereas many male homosexuals prefer to be called gay. Being gay is not a disease, a mental illness, or a choice. The American Psychiatric Association removed homosexuality from its list of mental disorders in 1973.

Estimates of the prevalence of homosexuality in the general population range from about $2 \%$ to $10 \%-12 \%$. In multiple studies of gay men, the mean age of acknowledging sexual orientation has been identified retrospectively around the age of 13-14. Although these men usually did not consider themselves as gay until young adulthood, the feelings were there much earlier.

Because homosexuality is a sensitive subject for most adolescents, as well as their parents and teachers, we tend to avoid discussing it. Nevertheless, we may find ourselves in a situation in which a student asks us about sexual orientation. At one time or another, many adolescents wonder whether they are gay. For most, these are just mild concerns that cease as they grow older. For others, however, feelings about being gay can be confusing and emotional. As a result, they may "spend their time trying to look and act like other [adolescents] and being afraid to do anything that might make them different" (Gale, 1989, p. 111). Often they fight their feelings and, because of this insecurity, many adolescents tend to confuse masculinity/femininity with sexual orientation. The male who does not match the subjective definition of "masculine" or the female who does not match that of "femininity" are suspected of being gay.

For fear of arousing anyone's suspicions, adolescents often hesitant to discuss their feelings and think they are the only ones with the same feelings. Gay and lesbian adolescents are more likely than their heterosexual peers to drop out of school, become runaways, and abuse alcohol and other drugs. The suicide rate for gay and lesbian adolescents is two to six times higher than that of heterosexual adolescents (Pender, 1990).

In addition to the many emotions that gay and lesbian adolescents experience, they also must cope with parental, peer, and societal negative reactions to being gay. A significant amount of ridicule, discrimination, stigmatization, anger, and physical attacks (known as "gay-bashing) is directed at gays and lesbians simply because of their sexual orientation.

Although many sex education programs include the topic of sexual orientation, the information is limited and often presented in a negative, nonaccepting fashion. Many state man- 
dated HIV/AIDS education programs, however, have opened up discussions about sexual orientation. School districts are beginning to take the initiative in educating adolescents about sexual orientation and are beginning to provide more of a healthy and safe environment for students who consider themselves to be gay. As examples: schools in Los Angeles operate a counseling and support program called "Project 10" for gay and lesbian youth; in San Francisco each school is required to designate a "gay-sensitive" staff member to whom students can turn if they have concerns; and schools in Fairfax, Virginia, integrate homosexuality into the family living/sex education curricula (Humm, 1992).

\section{Sexual Harassment}

One of the most persistent problems related to the issue of sexual harassment has been the "absence of a widely agreed upon definition, one that is broad enough to comprehend the variety of experiences to which the term refers, and yet specific enough to be of practical use" (Fitzgerald, 1992, p. 9). Because of the confusion over a definition, many students hesitate to discuss incidents with other students or school administrators. Students often feel helpless and without witnesses. Further, the burden of proof falls largely on the adolescent. The other side of the coin is that many teachers hesitant to interact with their students (put their arms around students in a friendly manner) for fear of being falsely accused themselves.

According to the American Association of Colleges (1978), behaviors that may be considered sexual harassment include:

Verbal harassment or abuse

- Subtle pressure for sexual activity

- Sexist remarks about someone's clothing, body, or sexual activities

Unnecessary touching, patting, or pinching

Leering or ogling at someone's body or body parts

Demanding sexual favors accompanied by implied or overt threats concerning one's grades, etc.

A coed expressed the following emotions after being sexually harassed by one of her teachers: "I still slink down one hall, cowering, frightened because of a teacher whose classroom is there. . . . Whenever I see him, my heart jumps a beat, I begin to sweat and I try to avoid eye contact as he stares at me" (Seattle Times, 1993). This student's feelings were the result of numerous sexual harassment incidents such as the teacher passing her in the hall and blowing her a kiss or patting her on the back or the buttocks in class; calling her "sweetheart," "honey," and "cutie"; and walking by her desk and discreetly slipping his hand inside the waistband of her jeans. Ultimately, the student informed the school's administration about the harassment. After a year of investigations and interviews, the teacher was suspended without pay with a warning that further incidents would not be tolerated.

In terms of education, adolescents need to become aware of behaviors that are considered inappropriate and what to do if they believe they are being sexually harassed. In addition, administrators must establish a school atmosphere that encourages students to report these behaviors.

\section{Teaching Sex Education}

Because sex education is such a sensitive topic, a student's question or behavior at times may be beyond what a teacher feels comfortable or knowledgeable about discussing. A model developed by Jack Annon (discussed in Muccigrosso et al., 1991), the PLISSIT model, is designed to determine the parameters and when a referral to a professional in or outside of the school is indicated. The model outlines four levels of intervention: permission, limited information, specific suggestions, and intensive therapy.

Permission $(P)$. Some potential problems can be eliminated simply by giving permission to adolescents to experience their sexual development. Adolescents need to know they are normal in their sexuality, through statements such as, "All girls have periods. It's normal and part of being a girl. It means you're growing up, and that's exciting!" (Maksym, 1990, p. 109). This may be helpful in relieving anxiety over sexual thoughts, fantasies, and arousal (Kempton, 1988) for boys and girls alike.

Limited information (LI). This level of information provides more details but only enough to answer specific questions. Information presented through a sex education program must be keep simple: "Some bleeding comes from the vagina each month; it comes from the uterus inside the girl's body" (Maksym, 1990, p. 110). This type of information dispels myths and concerns about sexuality.

Specific suggestions (SS). Often questions can be answered by giving specific and concrete suggestions: For example, you might say to an adolescent, "Having a period is a private thing. You can talk about it just with your mother or your teacher or your best friend. Not to people on the bus, or people you don't know" (Maksym, 1990, p. 110).

Intensive therapy $(I T)$. Teachers should not provide intensive therapy unless they have been trained in both the physical and the psychological aspects of human sexuality. This is the level at which teachers usually suggest that the individual student obtain professional counseling.

A lot of information about human sexuality can be provided to students through informal and unplanned interactions. When discussing these topics, teachers should not overemphasize technical detail, or misrepresenting facts, or omit essential options. The goal is to provide accurate, complete, and relevant information so adolescents can make in- 
formed, responsible decisions. Throughout these interactions, the following personal characteristics are essential for effective instruction in human sexuality (Romaneck \& Kuehl, 1992), (p. 24):

1. Credibility. The ability to win the confidence and respect of students.

2. Knowledge. Awareness of the subject matter and confidence in one's ability to present the material in an open and straightforward manner.

3. Trust. Engendering in students the feeling that they can communicate freely and openly with the teacher.

4. Acceptance. The ability to accept individual differences.

5. Approachability. Communicating to students that they can express highly sensitive or private feelings to the teacher.

6. Flexibility. The capability of dealing with student input in a nonrigid fashion.

7. Authenticity. The ability to maintain an honest and sincere posture toward students.

Numerous commercial curricula are available for more formal sex education programs. Regardless of the program used, Thomas et al. (1985), have suggested that the following components be part of a sex education curriculum:

\section{Unit 1}

Introduction to human - access and laws

growth and development

Communication and decision making

\section{Unit 2}

Growing up male

- anatomy and physiology

- sexual orientation

-pressures

-laws

\section{Unit 3}

Growing up female

- anatomy and physiology

-sexual orientation

-pressures

-laws

\section{Unit 4}

Teen pregnancy

-health and psychosocial risks

\section{Unit 5}

Personal hygiene for males and females

\section{Unit 6}

Birth control

-benefits

-risks

\section{Unit 7} eases

- prevalence

-prevention

-detection

-treatment

-health risks

-laws

\section{Unit 8} ductive health

-smoking

\section{Unit 9}

Labor and pregnancy

Unit 10 nancy alternatives

\section{Unit 11}

Date rape and stranger rape

-prevalence

-prevention

-laws

Sexual harassment -prevalence

-prevention

-laws

Unit 12

Conclusion

In addition, Muccigrosso et al. (1991), have suggested some effective techniques for teaching sexuality to adolescents, as follows:

1. Draw out what the students already know or think they know.

2. Establish ground rules to make it safe to talk about sexuality, such as

- no put-downs

— don't share information outside of the class

- everyone can pass (e.g. refuse to discuss a topic)

- no private stories

- show respect for one another

- all questions are good questions.

3. Agree on commonly understood vocabulary.

4. Use visual aids such as models, videos, and slides.

5. Create opportunities for role plays.

6. Incorporate group discussions and cooperative learning.

7. Be as concrete as possible; demonstrate and illustrate.

8. When possible, have coeducational groups.

9. Team-teach- male and female whenever possible.

10. Start with topics that are comfortable to you and the students.

Sexually transmitted dis-

Factors influencing repro-

-alcohol and other drug use

-nutrition and medical care

Positive parenting and preg-

\section{SCHOOL DROPOUT}

Dropping out of school has a significant impact on a student's life as well as economic and social repercussions for the society at large. Unemployment rates are high among high school dropouts. In one study, $60 \%$ of dropouts in Miami and $46 \%$ in Philadelphia reported being unemployed and not enrolled in vocational or academic programs. In addition, high school dropouts who are employed tend to earn less than high school graduates (Dropouts' Perspective on Leaving School, 1988). The result is a loss of earnings, taxes, and social security, as well as a lack of qualified workers.

Most dropouts later regret their decision to leave school (Peng \& Takai, 1983). This dissatisfaction only intensifies the low self-esteem typical of dropouts (Ekstrom, Goertz, Pollack, \& Rock, 1986). Teachers, therefore, must provide appropriate opportunities for all students to learn, to be successful, and to graduate from high school as a means of reducing the ever-rising dropout-rates.

\section{Numbers of Dropouts}

One problem with the current research on dropouts is the lack of a standardized definition and in consistent accounting procedures across school district and research studies (MacMillan, Balow, Widaman, Borthwick-Duffy, \& Hendrick, 1990). The Office of Educational Research and Improvement 
(1987) defined a dropout as a student who leaves school before his or her program of study is complete, before graduation, without transferring to another school.

Another definition of school dropouts, by Voss, Wendling, and Elliott (1966) differentiated three types of dropouts:

1. Involuntary dropouts who have to leave school because of unavoidable circumstances such as a family emergency

2. Students ... who leave because they lack certain skills

3. Capable students who voluntarily drop out for other reasons.

A conservative estimate of the dropout rate nationwide is $15 \%-25.9 \%$ of all high school students (Mann, 1985; State Education Performance, 1990). The incidence of students with mild disabilities who drop out of school may significantly exceed that of the nondisabled; approximately one in four students with mild disabilities drop out of school (Cohen $\&$ deBettencourt, 1991).

Studies that report dropout rates separately for different categories of handicapping conditions generally indicate that two groups have a higher propensity than others to leave school before graduation. The estimated dropout rate of students with severe emotional disturbances is approximately $50 \%$ (Kaufman, 1987), and for adolescents with learning disabilities, between $25 \%$ and $50 \%$ (deBettencourt, Zigmond, \& Thornton, 1989). In a comparative study Zigmond and Thornton (1985), reported that half of the students with learning disabilities who began 9th grade left school before graduation. This rate was significantly higher than that for nondisabled adolescents in the same urban school.

\section{Kinds of Students Who Drop Out of School}

Numerous characteristics of students at risk for dropping out of school have been identified. Ekstrom and her colleagues (1986) focused on a sample of high school sophomores over a 2-year period and found that those who stayed in school ("stayers") differed from those who left ("leavers") across a wide variety of dimensions. Students in low socioeconomic and racial/ethnic minority groups were disproportionately represented among the leavers and were more likely to be older and male.

Specifically, these researchers found that the leavers tended to come from homes with fewer study aids and fewer opportunities for nonschool-related learning. Further, the leavers were less likely to have both birth parents living in the home, more likely to have employed mothers (who had less education and lower educational expectations for their children), and to have less parental monitoring of their in- and out-of-school activities.

The leavers also were less likely to be involved in extracurricular activities and had lower grades and test scores than the stayers. Too, the leavers did less homework- an av- erage of 2.2 hours a week compared to the 3.4 hours reported by the stayers. The leavers also had more discipline problems in school than the stayers, were absent and late more often, cut more classes, got suspended from school more often, and had more trouble with the police.

Differences between leavers and stayers also were found in the social domain. Many of the leavers reported feelings of alienation from school. Few leavers reported being satisfied with their academic work and being popular with other students. They tended to choose friends who also were alienated from school and who had low educational expectations. Finally, the leavers were likely to have worked more hours during their high school years than the stayers. Their jobs were more enjoyable and important to them than school. Additional characteristics of dropouts and related school factors are summarized in Table 6 .

Although the profile of adolescents who drop out of school helps to identify potential dropouts, the data do not tell us why these students decide to leave. Some say that factors identified by Ekstrom and her colleagues (e.g., truancy, poverty, low expectations) actually cause students to drop out of school (SMERC, 1986). Over the past 30 years dropouts have consistently reported (Dropouts' Perspective on Leaving School, 1988) their main reasons for leaving school before graduation as:
A dislike for school
The opinion that "school is boring" and not relevant Low academic achievement and poor grades
A desire to work full-time and a need for money
Lack of belonging and a sense that nobody cared.

\section{Prevention}

Literally thousands of school programs have been designed to reduce the number of students who drop out of school. Successful programs share several common features: small size, inclusion by choice, flexibility, view of school as a community, and involvement of the community outside the school (Cuban, 1989).

Nationwide, school districts are adopting a variety of programs to reduce high school dropout rates. The underlying premise of many of these programs is to provide opportunities for student success (ways to get students through school and to accumulate credits toward high school graduation) and to improve their self-image. Many interventions emphasize support systems designed to help students overcome obstacles such as low motivation and large class size. The programs also tend to stress flexibility with regard to course requirements and grading systems, school climate, support from teachers and administrators, teacher-student contact strategies, instructional approaches, and vocational and school-community educational programs (Cohen \& deBettencourt, 1991). 
TABLE 6

Characteristics of Drop-Out Students

\begin{tabular}{|c|c|}
\hline $\begin{array}{l}\text { Demographic Factors } \\
\text { Ethnic group } \\
\text { Gender } \\
\text { Community type }\end{array}$ & $\begin{array}{l}\text { School Factors } \\
\text { Weak leadership from the principal } \\
\text { High level of disempowerment experienced by staff }\end{array}$ \\
\hline $\begin{array}{l}\text { Social and Family Factors } \\
\text { Socioeconomic status } \\
\text { Single-parent family } \\
\text { Educational or motivational support at home }\end{array}$ & $\begin{array}{l}\text { Small amount of time teachers engage in instruction } \\
\text { Low percentage of teaching time spent in interactive learning } \\
\text { Tracking }\end{array}$ \\
\hline $\begin{array}{l}\text { Personality Factors } \\
\text { Low self-concept } \\
\text { Externalized locus of control } \\
\text { Low needs for self-development }\end{array}$ & $\begin{array}{l}\text { Misuse of standardized tests } \\
\text { Fiscal arrangements that encourage early dismissal of } \\
\text { dropouts }\end{array}$ \\
\hline $\begin{array}{l}\text { Early Transition into Adulthood } \\
\text { Pregnancy } \\
\text { Marriage } \\
\text { Having a job }\end{array}$ & $\begin{array}{l}\text { Overcrowding } \\
\text { Underachieving student body } \\
\text { High failure rates }\end{array}$ \\
\hline $\begin{array}{l}\text { Deviant Behavior in Society } \\
\text { Institutionalized or incarceration } \\
\text { Delinquency } \\
\text { Drug use }\end{array}$ & $\begin{array}{l}\text { Low degree of order and discipline } \\
\text { Low attendance rate }\end{array}$ \\
\hline $\begin{array}{l}\text { In-School Factors } \\
\text { Low academic achievement and low grades } \\
\text { Low IQ; reading problems } \\
\text { Being held back; being over age } \\
\text { Low educational and occupational aspirations } \\
\text { Behavior problems; poor attendance }\end{array}$ & School reform \\
\hline
\end{tabular}

Source: Wolman, C., Bruininks, R., \& Thurlow, M. L. (1989). Dropouts and dropout programs: Implications for special education. Remedial and Special Education, 10, 6-20. Reprinted with permission.

Some common dropout prevention programs are

$\square$ Remedial and basic skills classes

$\square$ Reading programs

Tutoring programs

Motivational development activities

$\square$ On-the-job training

School-supervised work experience

$\square$ Counseling activities

a Parental involvement

Self-awareness classes

- School-age parenting classes

Evening or weekend classes.

Generally, educators say the needs of students at risk for dropping out of school are complex and defy easy solutions (Rodenstein, 1990). Moreover, the reasons frequently are multiple (e.g., a young girl is pregnant, low-achieving, and poor) and vary from student to student.

\section{CRISIS INTERVENTION EFFORTS}

A number of professionals (Caplin, 1964; McWhirter et al., 1993) separate prevention into three levels: (a) primary prevention, efforts to reduce the incidence of involvement; (b) secondary prevention, efforts to work with adolescents who are involved already; and (c) tertiary prevention, efforts directed toward rehabilitation of the adolescent.

\section{Primary Prevention}

Primary prevention has been defined as "a process which promotes health by empowering people with the resources necessary to confront complex, stressful life conditions and by enabling individuals to lead personally satisfying, enriching lives, (Berkan, 1986, p. 4). This approach encompasses a variety of activities that help adolescents develop a positive self-image and better coping skills. Most primary prevention programs promote behavioral changes of adolescents to reduce their risk-taking behaviors. Shaw and Goodyear (1984) noted that primary prevention must:

-be group-oriented and individually focused.

- be a before-the-fact effort targeted to groups or individuals not yet involved in the social issue.

-rest on a solid knowledge base that suggests the program holds potential for preventing involvement (p. 625). 
Primary prevention approaches are of four main types: information, affective, alternative, and social competence (Elmquist, 1991).

Information. Prevention efforts are considered generic when they are thought to be appropriate for all students, not just those presumed to be at-risk. Often, these efforts are information-based with the assumption that more balanced, factual knowledge about the consequences of at-risk behaviors, such as alcohol and drug use, sexual behaviors, and so on, will create more negative attitudes toward and reduce the likelihood of the adolescent's involvement.

Educators must provide accurate and timely information about these social issues. Hansen et al. (1988) found that information about relatively immediate consequences had greater effect than information about long-term consequences. In addition, adolescents are more likely to be suspicious of information presented in an obviously one-sided and biased manner than information presented in a balanced and neutral manner (Botvin \& Willis, 1987).

The information approach includes scare tactics. We all have seen the television commercials that dramatically demonstrate the effects of drugs on the brain by cracking an egg into a sputtering skillet. However, scare tactics neither provide information nor prevent drug use (Horan \& Straus, 1987; Newcomb \& Bentler, 1989).

Fortunately, we are beginning to move away from the information approach. According to Goodstadt (1986), information-based efforts, especially alcohol and other drug-use education programs, have failed for four reasons: (a) changes in attitude do not automatically lead to changes in behavior; (b) alcohol and other use drug or sex education courses often are taught as though all students involved are nonusers or nonparticipants; (c) education programs do not make necessary links between the classroom and reality; and (d) most education programs have not been evaluated in terms of learning outcomes. Finally, Eiser, Eiser, and Bocker (1988) questioned teachers and found them dissatisfied with information-based interventions, preferring approaches based on teaching students how to make appropriate decisions.

Affective. Affective educational programs promote self-understanding and responsible decision making. They address value clarification, problem solving, self-awareness and selfesteem, and coping skills (Barnea, 1989; Jaker, 1985). An adolescent faces many decisions that require these skills (Should I have sex? Should I try marijuana? Should I have another beer?). This prevention/intervention approach is based on the assumption that by improving their psychological traits, clarifying values, and developing responsible patterns of assertiveness, refusal and decision making skills, and skills in resisting peer pressure, the adolescent will decide not to become involved in alcohol and drug use, sexual activities, and so on (Elmquist, 1991). For example, instead of focusing on actual alcohol and drug use, affective education programs attempt to eliminate the underlying reasons for their use (Bell \& Battjes, 1987). Several professionals (e.g., Moskowitz, 1989; Tobler, 1986), however, claim that affective education is ineffective in influencing values, self-esteem, or behaviors.

Alternatives. The alternative prevention approach is based on the premise that an individual exhibits risk-taking behaviors because of a need to be involved in rewarding, exciting, and thrilling activities (Barnea, 1989). Adolescents often drink alcohol because they want to belong and have fun with friends. To be effective, alternative intervention programs have to offer healthy, legal alternative activities, such as the alcohol and other drug use activities and clubs described earlier, as a means of meeting these needs (Bell \& Battjes, 1987).

Alternative programs have proven effective in decreasing alcohol and other drug use and in improving self-esteem, coping skills, relationships with family and friends, school attendance, school behavior, leadership skills, and academic performance (Contrucci, 1991). Participants enjoy a sense of belonging to a group that engages in meaningful, worthwhile activities where they have some responsibility and control. Using the dynamics of positive peer pressure, peer support, peer influences, and peer interaction, these programs bring together a group of unique and diverse students with the common interest of wanting to help others.

Social Competence. The social competence approach is based on the assumption that alcohol and other drug use, sexual activities, and so on often are a result of poor personal and social competence (Elmquist, 1991). An adolescent with appropriate social skills can resist and counter these pressures (Botvin, 1983).

A major component of this approach is active student participation through peer helper programs. Specially selected, responsible students are trained in specific skills and are given the opportunity to have a positive influence on their fellow students (see Contrucci, 1991 for selection and training procedures).

\section{Secondary Prevention}

Secondary prevention involves identifying adolescents who show beginning signs of depression or involvement in undesirable behaviors for whom prompt diagnosis and effective treatment might ward off more serious involvement. Simply, it is the action taken following recognition of the problem, such as the steps discussed earlier related to teenage depression and suicide.

\section{Tertiary Prevention}

Tertiary prevention consists of treating adolescents who are seriously involved in alcohol and drug abuse, sexual activities, and so on. This treatment is similar to the concept of 
rehabilitation - to help those who already are affected to lead as normal a life as possible (for more information see Adams \& Gullota, 1989, Thompson \& Rudolph, 1992).

\section{COMPREHENSIVE EFFORTS}

Schools should adopt a comprehensive prevention approach because no one approach reaches every adolescent. A comprehensive approach differs from what many schools and educators currently provide, such as the problem-of-the-week approach (Jessor, 1991) wherein efforts are mobilized to fight teenage pregnancy one week, drunk driving the next, alcohol and drug use the next, and so on.

A comprehensive approach is based on the assumption that many adolescents are involved not only in alcohol and other drug use but also in risky sexual activities. For example, the three behaviors that place individuals at highest risk for HIV infection typically are initiated during adolescence. These are (a) unprotected sexual intercourse, (b) intravenous drug use, and (c) the use of drugs and alcohol before or during sexual behavior (Rotheran-Borus \& Koopman, 1991). Professionals have identified common components of comprehensive dropout prevention programs (Guetzloe, 1988; Rogers, 1991):

1. Initiated early and dealt with antecedents, not results of failure.

2. Gave one-on-one attention to students.

3. Supplied, fostered, and encouraged the development of basic skills and socialization skills.

4. Located in school and involved parents, students, and educators.

5. Had an obvious connection with the real world.

6. Had exciting leaders who related well to adolescents.

7. Were broad-based, communitywide efforts.

8. Involved multiple agencies.

Dryfoos (1991) provided examples of successful communitywide prevention programs that incorporated different kinds of programs and services (e.g., schools, public and private community agencies, parent groups, media, police, courts, clergy, businesses, universities, and students). For example, a number of efforts combined community education, media, and school interventions. In the alcohol and other drug abuse area, a communitywide health promotion campaign used local media and community education in conjunction with alcohol and other drug use prevention curricula in the local schools. A successful program in pregnancy prevention concentrated on community education through the media and a speaker's bureau; training of parents, clergy, and other community leaders; and development and implementation of comprehensive sex and family life education unit in the schools. In another example a school dropout program was implemented successfully by an allout community effort that involved the schools with local businesses, local government agencies, and universities in planning, teacher training, and training and job placement of adolescents.

\section{SUMMARY AND CONCLUSION}

As we explore adolescent's, involvement in social issues, and as we consider prevention and intervention activities, we must keep in mind the enormous changes adolescents go through. The dramatic physical, emotional, psychological, and social changes of adolescence occur rapidly, at a rate unsurpassed at any later point in life. To this great change within adolescents we must add the changes in social expectations, changes in the structure and content of formal education, the effects of difficult conditions in our society, and the effects of having a mild disability. Only then can educators imagine how tough the transition into adulthood can be for many adolescents. As educators, we must ask how we can establish more supportive environments for adolescents' transition to adulthood in a society that place many obstacles in their paths. Hepworth and Shernoff (1989) contend that, "to be effective, education must motivate people to recognize personal risk and to take action to change behaviors that put them at risk" (p. 48).

\section{REFERENCES}

Adams, G. R., \& Gullota, T. (1989). Adolescent life experiences. (2d ed.) Pacific Grove, CA: Brooks/Cole.

American Academy of Pediatrics. (1988). Substance abuse: A guide for health Professionals. Elk Grove Village, IL: Author.

American Association of Colleges (1978). Sexual harassment: A hidden issue. Washington, DC: Author.

American College Health Association (1990). HIV infection and AIDS. Baltimore, MD: Author

American Psychological Association. (1987). Diagnostic and statistical manual of mental disorders (3d ed. rev.) Washington, DC: Author.

Anderson, J. E., Kann, L., Haltzman, D., Arday, S., Truman, B., \& Kolbe, L. (1990). HIV/AIDS knowledge and sexual behavior among high school students. Family Planning Perspectives, 22, 252-255.

Barnea, Z. (1989). A critical an comparative review of the prevention of drug and alcohol abuse in Israeli Journal of Drug Education, $19,59-81$.

Beck, A. T., Ward, C. H., Mendelson, M., Mock, J., \& Erbaugh, J. (1961). An inventory for measuring depression. Archives of General Psychiatry, 4, 53-63.

Beck, A. T., Kovacs, M., \& Weissman, A. (1979). Assessment of suicidal ideation: The Scale of Suicidal Ideation. Journal of Clinical and Consulting Psychology, 47, 343-352.

Bell, C. S., \& Battjes, R. J. (1987). overview of drug abuse prevention research. In C. S. Bell \& R. J. Battjes (Eds.), Prevention research: Determining drug abuse among children and adolescents (National Institute on Drug Abuse research Monograph 
No. 63, DHHS Publication No. ADM-85-1334). Washington, DC: U. S. Government Printing office.

Berkan, W. A. (1986). Suicide prevention: A resource and Planning guide. Madison: Wisconsin Department of Public Instruction.

Botvin, G. J. (1983). Life skills training (Teacher's Manual). New York: Smithfield.

Botvin, G. J., \& Willis, T. A. (1987). Personal and social skills training: Cognitive-behavioral approaches to substance abuse prevention. In C. S. Bell \& R. J. Battjes (Eds.), Prevention research: Determining drug abuse among children and adolescents (National Institute on Drug Abuse research Monograph No. 63, DHHS Publication No. ADM-85-1334). Washington, DC: U.S. Government Printing Office.

Brooks-Gunn, J., Boyer, C. B., \& Hein, K. (1988). Preventing HIV infection and AIDS in children and adolescents: Behavioral research and intervention strategies. American Psychologist, 43, 958-964.

Caplin, G. (1964). Principles of preventive psychiatry. New York: Basic Books.

Capuzzi, D., \& Golden, L. (1988). Adolescent suicide: An introduction to issues and interventions. In D. Capuzzi \& L. Golden (eds.), Preventing adolescent suicide (pp. 3-28). Muncie, IN: Accelerated Development.

Capuzzi, D., \& Le Coq, L. L. (1983). Social and personal determinants of adolescent use and abuse of alcohol and marijuana. Personnel and Guidance Journal, 61, 199-205.

Centers for Disease Control. (1989). AIDS cases reported through November 1989. HIV/AIDS surveillance. Issue December. Atlanta, GA: Author.

Children and Teens Today Newsletter (1987, February), p. 3.

Cohen, S. G., \& deBettencourt, L. V. (1991). Dropout: Intervening with the reluctant learner. Intervention in School and clinic, 26, 263-271.

Coles, R. , \& Stokes, G. (1985). Sex and the American teenager. NY: Rolling Stone Press.

Conger, J. J. (1988). Hostages to fortune: Youth, values, and the public interest. American Psychologist, 43, 291-300.

Contrucci, V. J. (1991). Alcohol and other drug abuse programs: A resource and planning guide. Madison: Wisconsin Department of Public Instruction.

Cuban, L. (1989). At-risk students: What teachers and principals can do. Educational Leadership, 45, 29-33.

Dean, J. C., Fox, A. M., \& Jensen, W. (1985). Alcohol and drug use by disabled and nondisabled persons: A comparative study. The International Journal of the Addictions, 20, 629-641.

deBettencourt, L. U., Zigmond, N., \& Thornton, H. (1989). Followup of rural learning disabled graduates and dropouts. Exceptional Children, 56, 40-49.

Devlin, S. D., \& Eliott, R. N. (1992). Drug use patterns of adolescents with behavioral disorders, 17, 264-272.

DiNitto, D. M., \& Krishef, K. (1984). Drinking patterns of mentally retarded persons. Alcohol, Health, and Research World, 8, 40-42.

Dollinger, S. J., Horn, J. L., \& Boarini, D. (1988). Disturbed sleep and worries among learning disabled adolescents. American Journal of Orthopsychiatry, 58, 428-434.

Dropouts' Perspective on Leaving School (1988). CAPS Capsule, 2-3.
Dryfoos, J. G. (1991). Adolescents at risk: Prevalence and prevention. New York: Oxford University Press.

Edeleman, M. W. (1987). Families in peril: An agenda for social change. Cambridge, MA: Harvard University Press.

Eiser, C., Eiser, J. R., \& Bocker, M. (1988). Teachers, evaluation of a "life-skills" approach to drug education. Educational Research, 30, 202-210.

Ekstrom, R. B., Goertz, M. E., Pollack, J. M., \& Rock, D. A. (1986). Who drops out of high school and why? Findings from a national study. Teacher's College Record, 87, 356-373.

Elmquist, D. L. (1991). School-based alcohol and other drug prevention programs: Guidelines for the special educator. Intervention in School and clinic, 27, 10-19.

Elmquist, D. L., Morgan, D. P., \& Bolds, P. (1989). Substance abuse among adolescents with disabilities. Unpublished manuscript, Utah State University, Department of Special Education, Logan.

Fick, L. (1984). Adolescent childbearing decisions: Implications for preventing. St. Louis, MO: The Danforth Foundation.

Fitzgerald, L. F. (1992). Sexual harassment in higher education: Concepts and issues. Washington, DC: National Education Association.

Foster, S. (1986). Preventing teenage pregnancy. Washington, DC: Council of State Policy and Planning Agencies.

Frederick, C. I. (1985). An introduction and overview of youth suicide. In M. L. Peck, N. L. Farberow, \& R. E. Litman (Eds.), Youth suicide (pp. 1-33). New York: Springer-Verlag.

Gale, J. (1989). A parent's guide to teenage sexuality. Henry Holt: New York.

Garrison, C. Z., Lewinsohn, P. M., Marsteller, F., Langhinrichsen, J., \& Lann, I. (1991). The assessment of suicidal behavior in adolescents. Suicide and Life-Threatening Behavior, 21, 217-230.

Gibbs, N. (1993, May 24). How should we teach our children about sex? Time, 60-66.

Gispert, M., Wheeler, K., Marsh, L., \& Davis M. S. (1985). Suicide adolescents: Factors in evaluation. Adolescence, 20, 753-761.

Goodstadt, M. S. (1986). School-based drug education in North America: What is wrong? What can be done? Journal of School Health, 56, 278-281.

Guetzloe, E. C. (1987). Suicide and depression, the adolescent epidemic: Education's responsibility. Orlando, FL: Advantage Consultants.

Guetzloe, E. C. (1988). Suicide and depression: Special education's responsibility. Teaching Exceptional children, 20, 25-28.

Hansen, W. B., Graham, J. W., Wolkenstein, B. H., Lundy, B. Z., Pearson, J., Flay, B. R., \& Anderson-Johnson, C. (1988). Differential impact of three alcohol prevention curricula on hypothesized mediating variables. Journal of Drug Education, 18, 143-153.

Harrell, A. V., \& Wirtz, P. W. (1989). Adolescent drinking-index. Odessa, FL: Psychological Assessment Resources, Inc.

Harris, L. (1987). Inside America. New York: Vintage.

Hawton, K. (1986). Suicide and attempted suicide among children and adolescents. Beverly Hills, CA: Sage.

Hayes, M. L., \& Sloat, R. S. (1988). Suicide and the gifted adolescent. Journal for the Education of the Gifted, 13, 229-244.

Hein, K. (1989). AIDS in adolescence: Exploring the challenge. Journal of Adolescent Health Care, 10, 105-355. 
Hendlin, H. (1982). Suicide in America. New York: W. W. Horton. Hepworth, J., \& Shernoff, M. (1989). Strategies for AIDS education and prevention. In E. Macklin (ed.), AIDS and Families, p. 35-48. New York: Harrington Press.

Hingson, R. W., Strunin, L., Berlin, B. M., Heeren, T. (1988). Beliefs about AIDS, use of atcohol and drugs, and unprotected sex among Massachusetts adolescents. American Journal of Public Health, 78, 460-461.

Hofferth, S. L., Kahn, J. R., \& Baldwin, W. (1987). Premarital sexual activity among U.S. teenage women over the past three decades. Family Planning Perspectives, 19, 46-53.

Horan, J. J., \& Straus, L. K. (1987). Substance abuse. In M. Hersen \& V. B. VanHasselt (eds.), Behavior therapy with children and adolescents: A clinical approach (pp. 440-464). New York: Wiley.

Horton, L. (1985). Adolescent drug abuse. Bloomington, IN: Phi Delta Kappa Educational Foundation.

Humm, A. J. (1992). Homosexuality: The new frontier in sexuality education. Family Life Educator, 10, 13-18.

Issacs, M., Buckley, G., \& Martin, D. (1979). Patterns of drinking among the deaf. The American Journal of Alcohol and Drug Abuse, 6, 463-476.

Jaker, G. F. (1985, August). Lessons learned: A review of the research in drug education. Anoka: Minnesota Prevention Resource Center.

Jessor, R. (1991). Risk behavior in adolescence: A psychosocial framework for understanding and action. Journal of Adolescent Health, 12, 597-605.

Johnston, J., O’Malley, P. M., \& Bachman, J. G. (1986). Drug use among American high school students, college students, and other young adults. Washington, DC: U.S. Government Printing Office.

Kellam, S. G., \& Simon, M. C. (1980). Mental health in first grade and teenage drug, alcohol and cigarette use. Journal of Drug and Alcohol Dependency, 5, 273-304.

Kempton, W. (1988). A teacher's guide: Sex education for persons with disabilities. Santa Monica, CA: Stanfield.

Kirby, D. (1984). Sexuality education: An evaluation of programs and their effect. Santa Cruz, CA: Network.

Kosky, P. (1983). Childhood suicidal behavior. Journal of Child Psychology and Psychiatry, 24, 457-467.

Krishef, C. H. (1986). Do the mentally retarded drink? A study of their alcohol usage. Journal of Alcohol and Drug Education, 31, 64-70.

Leone, P. E., Greensburg, J. M., Trickett, E. J., \& Spero, E. (1989). A study of the use of cigarettes, alcohol, and marijuana by students identified as seriously emotionally disturbed. Counterpoint, 9, 6-7.

Long, J. V. F., \& Scherl, D. J. (1984). Developmental antecedents of compulsive drug use: A report on the literature. Journal of Psychoactive Drugs, 16, 169-182.

Maag, J. W., \& Behrens, J. T. (1989). Epidemiologic data on seriously emotionally disturbed and learning disabled adolescents reporting extreme depressive symptomatology. Behavioral Disorders, 15, 21-27.

MacDonald, D. I., \& Blume, S. B. (1986). Children of alcoholics. American Journal of Disorders of Children, 140, 750-754.

MacMillan, D. L., Balow, I. H., Widaman, K. F., Borthwick-Duffy, S., \& Hendrick, I. G. (1990). Methodological problems in estimating dropout rates and the implications for studying dropouts from special education. Exceptionality, 1, 29-39.
Maksym, D. (1990). Shared feelings: A parent guide to sexuality education for children, adolescents and adults who have a mental handicap. North York, Ontario: The G. Allan Roeher Institute.

Mann, D. (1985). Action on dropouts. Educational Leadership, 43, 16-17.

Mann, D. (1986). Can we help dropouts: Thinking about the undoable. Teachers College Record, 87, 307-323.

McGee, K., \& Guetzloe, E. (1988). Suicidal emotionally handicapped students: Tips for the classroom teacher. The Pointer, 32, 7-10.

McWhirter, J. J. (1993). Will he live? A suicide assessment interview. In L. Golden \& M. Norwood (eds.), Case studies in child counseling (pp. 89-98). New York: MacMillan.

McWhirter, J. J., McWhirter, B. T., McWhirter, A. M., \& McWhirter, E. H. (1993). At-risk youth: A comprehensive response. Pacific Grove, CA: Brooks/Cole.

Metha, A., \& Dunham, H. (1988). Behavioral indicators. In D. Capuzzi \& L. Golden (eds.), Preventing adolescent suicide (pp. 49-86). Muncie, IN: Accelerated Development.

Morbidity and Mortality Weekly Report. (1988, January 29). Guidelines for effective school health education to prevent the spread of AIDS. Atlanta, GA: Centers for Disease Control.

Moskowitz, J. M. (1989). The primary prevention of alcohol problems: A critical review of the research literature. Journal of Studies on Alcohol, 50, 54-88.

Muccigrosso, L., Scavarda, M., Simpson-Brown, R., \& Thalacker, B. E. (1991). Double Jeopardy: Pregnant and parenting youth in special education. Reston, VA: Council for Exceptional children.

National Academy of Sciences. (1989). Confronting AIDS: Directions for public health, health care, and research. Washington, DC: Author.

Newcomb, M. D.,\& Bentler, P. M. (1989). Substance use and abuse among children and teenagers. American Psychologist, 44, 242-248.

Office of Educational Research and Improvement. (1987). Dealing with dropouts: The urban superintendents' call to action. Washington, DC: U.S. Government Printing Office.

Office of Population Affairs. (1988, November). Family life information exchange. U.S. Department of Health and Human Services, Public Health, Resource Memo. Washington, DC:

Orr, D. P., Wilbrant, M. L., Brack, C. J., Rauch, S. P., \& Ingersoll, G. M. (1989). Reported sexual behaviors and self-esteem among young adolescents. American Journal of Diseases of Children, $143,86-90$.

Otto, U. (1972). Suicidal acts by children and adolescents. Acta Psychiatry Scandinavia, 233, 7-123.

Paget, K. (1988). Adolescent pregnancy: Implications for prevention strategies in educational settings. School Psychology Review, 17, 570-579.

Peck, M. L. (1985). Crisis intervention treatment with chronically and acutely suicidal adolescents. In M. Peck, N. Farberow \& R. Litman (eds.), Youth suicide (pp. 1-33). New York: SpringerVerlag.

Pender, L. (1990). Growing up gay. Cincinnati Magazine (February). 26-29.

Peng, S. S., \& Takai, R. T. (1983). High school dropouts: Descriptive information from high school and beyond. Washington, DC: National Center for Educational Statistics (ERIC No. ED 236-366). 
Pfeffer, C. R. (1986). The suicidal child. New York Guilford Press.

Pfeffer, C. R., Zuckerman, S., Plutchik, R., Mizruchi, M. S. (1984). Suicidal behavior in normal school children: A comparison with child psychiatric patients. Journal of American Academy of Child Psychiatry, 23, 416-423.

Price, M. (1987, December). Physically, mentally disabled teens require special contraceptive care. Contraceptive Technology Update, 154-156.

Reynolds, (1985). Depression in childhood and adolescence: Diagnosis, assessment, intervention strategies, and research. In T. R. Kratochwill (ed.), Advances in school psychology (Vol. 4, pp. 133-189). Hillsdale, NJ: Lawrence Erlbaum.

Ritter, D. R. (1989). Social competence and problem behavior of adolescent girls with learning disabilities. Journal of Learning Disabilities, 22, 460-461.

Robertson, D., \& Mathews, B. (1989). Preventing adolescent suicide with group counseling. Journal for Specialists in Group Work, 14, 34-39.

Rodenstein, J. M. (1990). Children at-risk: A resource and planning guide. Madison: Wisconsin Department of Public Instruction.

Rogers, D. E. (1991). Adolescents at risk conference: Summation. Journal of Adolescent Health, 12, 644-647.

Romaneck, G. M., \& Kuehl, R. (1992). Sex education for students with high-incidence special needs. Teaching Exceptional Children, 25, 22-24.

Rotheran-Borus, M. J., \& Koopman, C. (1991). HIV and adolescents. The Journal of Primary Prevention, 12, 65-82.

Rutter, M. (1986). Depressive feelings, cognitions, and disorders: A research postscript. In M. Rutter, C. E. Izard, \& P. B. Read (eds.), Depression in young people (pp. 491-519). New York, NY: Guilford Press.

Schorr, L. B. (1988). Within our reach: Breaking the cycle of disadvantage. New York: Doubleday.

Seattle Times (November 2, 1993). The pain of harassment. p. E-8.

Shaffer, D. (1974). Suicide in childhood and early adolescence. Journal of Childhood Psychology and Psychiatry, 15, 275-291.

Shapiro, C. (1981). Adolescent pregnancy prevention: School-community cooperation. Springfield, IL: Charles C. Smith.

Slavin. R. E., Karweit, N. L., \& Madden, N. A. (1989). Effective programs for students at risk. Boston: Allyn \& Bacon.
SMERC. (1986 January). Information for professional excellence: Dropouts. Redwood City, CA: San Mateo County Office of Education.

State Education Performance, 1982 and 1989. (1990, May 9). Education Week.

Steele, W. (1983). Preventing teenage suicide. Novato, CA: Ann Arbor Publishers.

Strunin, L., \& Hingson, R. (1987). Acquired immunodeficiency syndrome and adolescents: Knowledge, beliefs, attitudes, and behavior. Pediatrics, 79, 825-828.

Sturner, W. Q. (1986). Adolescent suicide fatalities. Rhode Island Medical Journal,. 69, 471-474.

Tatum, M. L. (1988). The AIDS challenge: Controversial issues in the classroom. Family Life Educator, 7, 15-19.

Thomas, L. L., Long, S. E., Whitten, K., Hamilton, B., Fraser, J., \& Askins, R. V. (1985). High school students' long-term retention of sex education information. Journal of School Health, 55, 274-278.

Tobler, N. (1986). Meta-analysis of 143 adolescent drug prevention programs: Quantitative outcome results of program participants compared to a control or comparison group. Journal of Drug Issues, 16, 537-567.

Tomaszewski, E. P. (1991). Adolescent dating violence. Family Life Educator, 10, 4-8.

Tomlinson-Keasey, C., \& Keasey, C. B. (1988). "Signatures" of suicide. In D. Capuzzi \& L. Golden (eds.), Preventing adolescent suicide (pp. 213-245). Muncie, IN: Accelerated Development.

Tomlinson-Keasey, C., Warren, L. W., \& Elliott, J. E. (1986). Suicide among gifted women: A perspective study. Journal of Abnormal Psychology, 95, 123-129.

Voss, H. L., Wendling, A., \& Elliott, D. S. (1966). Some types of high-school dropouts. Journal of Educational Research, 59, 363-368.

Webb, J. A., Baer, P. E., McLaughlin, R. J., McKelvey, R. S., \& Caid, C. D. (1989). Risk factors and their relation to initiation of alcohol use among early adolescents. Journal of American Academy of Child and Adolescent Psychiatry, 30, 563-568.

Zigmond, N., \& Thornton, H. (1985). Follow-up of postsecondary age learning disabled graduates and drop-outs. Learning Disabilities Research, 1, 50-55.

PERMISSIONS AND COPYRIGHT • All rights are reserved. No part of this publication may be reproduced, photocopied, faxed, stored in a retrieval system, or transmitted, in any form or by any means, electronic, mechanical, recording or otherwise, without the prior written permission of the publisher. - Back issues are available for sale. Reproduction requires permission and payment of fees. It is illegal and a violation of federal copyright law to reproduce this publication without permission. Direct all inquiries to the permissions editor. 